Article

\title{
Integrative Descriptions of Two New Mesobiotus Species (Tardigrada, Eutardigrada, Macrobiotidae) from Vietnam ${ }^{\dagger}$
}

\author{
Daniel Stec ${ }^{1,2}$
}

check for

updates

Citation: Stec, D. Integrative

Descriptions of Two New Mesobiotus Species (Tardigrada, Eutardigrada, Macrobiotidae) from Vietnam.

Diversity 2021, 13, 605.

https://doi.org/10.3390/d13110605

Academic Editor: Michael Wink

Received: 2 November 2021

Accepted: 16 November 2021

Published: 21 November 2021

Publisher's Note: MDPI stays neutral with regard to jurisdictional claims in published maps and institutional affiliations.

Copyright: (C) 2021 by the author. Licensee MDPI, Basel, Switzerland. This article is an open access article distributed under the terms and conditions of the Creative Commons Attribution (CC BY) license (https:/ / creativecommons.org/licenses/by/ $4.0 /)$.
1 Institute of Systematics and Evolution of Animals, Polish Academy of Sciences, Sławkowska 17, 31-016 Kraków, Poland; daniel.stec@isez.pan.krakow.pl

2 Department of Invertebrate Evolution, Institute of Zoology and Biomedical Research, Faculty of Biology, Jagiellonian University, Gronostajowa 9, 30-387 Kraków, Poland

+ urn:lsid:zoobank.org:act:6ABF8C3D-FDD1-4DE0-88C8-54F49E21EFB4 (Mesobiotus imperialis sp. nov.); urn:lsid:zoobank.org:act:26C5E830-9A84-4019-B3A4-301339FE3220 (Mesobiotus marmoreus sp. nov).

\begin{abstract}
To date, 34 tardigrade taxa have been recorded from Vietnam and this includes only two macrobiotid species belonging to the genus Mesobiotus. In this paper, two additional species of this genus, one of the M. harmsworthi group and one of the $M$. furciger group, are reported and described as new for science (Mesobiotus imperialis sp. nov., Mesobiotus marmoreus sp. nov.). Both descriptions have an integrative character providing detailed morphological and morphometric data collected by phase contrast and scanning electron microscopy that are linked to genetic data. The latter constitute DNA sequences of molecular markers that are commonly used in tardigrade taxonomy. The genus phylogeny is also provided, elucidating the phylogenetic position of the newly discovered taxa.
\end{abstract}

Keywords: Mesobiotus harmsworthi group; Mesobiotus furciger group; morphogroup; new species; tardigrades; taxonomy; phylogeny

\section{Introduction}

Tardigrades, also known as water bears, are a phylum of microscopic animals whose body size usually does not exceed $1 \mathrm{~mm}$. These organisms are ubiquitous as they are found in marine, freshwater and various limno-terrestrial habitats all over the world [1]. To date, more than 1300 species have been formally described and, interestingly, a great majority of them were found in mosses and lichens [2-4].

The genus Mesobiotus was founded five years ago by Vecchi et al. [5] based on morphological distinctions from other genera within Macrobiotidae. The composition was further supported by phylogenetic analyses confirming the newly proposed taxon to be monophyletic [5] and, as such, was also recovered in the recent phylogeny of the family Macrobiotidae [6]. Now, the genus comprises 71 nominal species that are grouped into two unformal complexes, namely the Mesobiotus harmsworthi group and the Mesobiotus furciger group $[4,7,8]$. Although this morphological clustering of Mesobiotus taxa helps other researchers in taxonomic studies devoted to these macrobiotids, it has been demonstrated that the grouping does not reflect the phylogenetic relationship within the genus $[6,7,9]$. Out of 34 species representing he currently known tardigrade fauna of Vietnam [10-16], only two belong to the genus Mesobiotus. The first one is Mesobiotus harmsworthi (Murray, 1907) [17], the type species for the genus, as well as the recently discovered Mesobiotus datanlanicus Stec, 2019 [15]. Notably, according to the recent redescription the occurrence of M. harmsworthi in Vietnam, it should be treated with great caution [9].

In the present study, two new Mesobiotus species are described by means of an integrative taxonomy approach. Both descriptions comprise detailed morphological and morphometric data collected under phase contrast and scanning electron microscopy (PCM and SEM, respectively). Furthermore, phenotypic data DNA sequences of molecular mark- 
ers used as a standard in tardigrade taxonomy are provided for each analysed species. Finally, the phylogenetic tree presenting the position of both new taxa is also presented.

\section{Material and Methods}

\subsection{Sample Processing}

Two moss samples containing new species were collected in Huê and in the Marble Mountains, south of Đà Nẵng city (Vietnam). The samples were collected by Daniel Stec and Krzysztof Miler in August 2018 from tree bark and a stone walkway, respectively. The samples were examined for terrestrial tardigrades using standard methods (e.g., Stec et al. [18]). A total of 75 and 56 animals as well as 55 and 13 eggs of the two new species were extracted from both samples, respectively. In order to perform integrative taxonomic descriptions, the isolated animals and eggs were split into three groups for specific analyses: Morphological analysis with phase contrast light microscopy, morphological analysis with scanning electron microscopy and DNA sequencing (for details please see sections "Material examined" provided below for each description).

\subsection{Microscopy and Imaging}

Specimens for light microscopy were mounted on microscope slides in a small drop of Hoyer's medium and secured with a cover slip, following the protocol by Morek et al. [19]. Slides were then dried for five to seven days at $60{ }^{\circ} \mathrm{C}$. Dried slides were sealed with a transparent nail polish and examined under an Olympus BX53 light microscope with phase contrast (PCM), as well as with an Olympus DP74 digital camera. Immediately after mounting the specimens in the medium, slides were checked under PCM for the presence of males and females in the studied population, as the spermatozoa in testis and vas deferens are visible only for several hours after mounting $[20,21]$. In order to obtain clean eggs for SEM, eggs were processed according to the protocol by Stec et al. [18]. In short, eggs were first subjected to a water/ethanol and an ethanol/acetone series, then to $\mathrm{CO}_{2}$ critical-point drying and finally sputter-coated with a thin layer of gold. Specimens were examined under high vacuum in a Versa 3D DualBeam Scanning Electron Microscope at the ATOMIN facility of the Jagiellonian University, Kraków, Poland. All figures were assembled in Corel Photo-Paint X6. For structures that could not be satisfactorily focused on in a single photograph, a stack of 2-6 images were taken with an equidistance of ca. $0.2 \mu \mathrm{m}$ and assembled manually into a single deep-focus image.

\subsection{Morphometrics and Morphological Nomenclature}

All measurements are given in micrometres $(\mu \mathrm{m})$. Sample size was adjusted following recommendations by Stec et al. [22]. Structures were measured only if their orientation was suitable. Body length was measured from the anterior extremity to the end of the body, excluding the hind legs. The buccal apparatus and claws were classified according to Pilato and Binda [23] and Vecchi et al. [5], respectively. The terminology used to describe the oral cavity armature and the egg-shell morphology follows Michalczyk and Kaczmarek [24] and Kaczmarek and Michalczyk [25]. The macroplacoid length sequence is given according to Kaczmarek et al. [26] whereas morphological states of cuticular bars on legs follow Kiosya et al. [27]. The buccal tube length and the level of the stylet support insertion point were measured according to Pilato [28]. The $p t$ index is the ratio of the length of a given structure to the length of the buccal tube expressed as a percentage (Pilato 1981). All other measurements and nomenclature follow Kaczmarek and Michalczyk [25]. The buccal tube width was measured as the external and internal diameter at the level of the stylet support insertion point. The lengths of the claw branches were measured from the base of the claw (i.e., excluding the lunula) to the top of the branch, including accessory points. The distance between egg processes was measured as the shortest distance between the base edges of the two closest processes. Morphometric data were handled using the "Parachela" ver. 1.8 template available from the Tardigrada Register [29] and are given in Supplementary Materials (SM.1 and SM.2). T-test comparisons of morphometric characters 
of one of the new species and Mesobiotus philippinicus Mapalo, Stec, Mirano-Boscos \& Michalczyk, 2016 [30] were conducted using the statistical programming language R [31]. Since multiple testing inflates the Type I error rate, the Benjamini-Hochberg correction to the $\alpha$-level was applied [32] independently to each of the three sets of $t$-tests (absolute and relative animal measurements as well as egg measurements). Results of the $t$-tests are given in Supplementary Materials (SM.3). The taxonomic keys for the genus Mesobiotus by Kaczmarek et al. [7] and Tumanov [8] were used to determine whether the isolated species had previously been described. The tardigrade taxonomy follows Stec et al. [6].

\subsection{DNA Sequencing}

The DNA was extracted from individual animals following a Chelex ${ }^{\circledR} 100$ resin (BioRad) extraction method by Casquet et al. [33] with modifications described in detail in Stec et al. [34]. Four DNA fragments differing in mutation rates were sequenced. Namely, the small ribosome subunit (18S rRNA, nDNA), the large ribosome subunit ( $28 \mathrm{~S}$ rRNA, nDNA), the internal transcribed spacer (ITS-2, nDNA), and the cytochrome oxidase subunit I (COI, mtDNA). All fragments were amplified and sequenced according to the protocols described in Stec et al. [34]; primers are listed in Table 1. Sequencing products were read with the ABI 3130xl sequencer at the Molecular Ecology Lab, Institute of Environmental Sciences of the Jagiellonian University, Kraków, Poland. Sequences were processed in BioEdit ver. 7.2 .5 [35] and submitted to GenBank. Prior to submission, all obtained COI sequences were translated into protein sequences in $M E G A 7$ version 7.0 [36] to check against pseudogenes.

Table 1. Primers with their original references used for amplification of the four DNA fragments sequenced in the study.

\begin{tabular}{|c|c|c|c|c|}
\hline DNA Marker & $\begin{array}{l}\text { Primer } \\
\text { Name }\end{array}$ & $\begin{array}{c}\text { Primer } \\
\text { Direction }\end{array}$ & Primer Sequence $\left(5^{\prime}-3^{\prime}\right)$ & Primer Source \\
\hline \multirow{2}{*}{ 18S rRNA } & 18S_Tar_Ff1 & forward & AGGCGAAACCGCGAATGGCTC & \multirow{2}{*}[37]{} \\
\hline & 18S_Tar_Rr1 & reverse & GCCGCAGGCTCCACTCCTGG & \\
\hline \multirow{2}{*}{ 28S rRNA } & 28S_Eutar_F & forward & ACCCGCTGAACTTAAGCATAT & {$[38]$} \\
\hline & 28SR0990 & reverse & CCTTGGTCCGTGTTTCAAGAC & [39] \\
\hline & ITS2_Eutar_Ff & forward & CGTAACGTGAATTGCAGGAC & \multirow{2}{*}[40]{} \\
\hline ITS-2 & ITS2_Eutar_Rr & reverse & TCCTCCGCTTATTGATATGC & \\
\hline \multirow{2}{*}{ COI } & LCO1490-JJ & forward & CHACWAAYCATAAAGATATYGG & \multirow{2}{*}{ [41] } \\
\hline & HCO2198-JJ & reverse & AWACTTCVGGRTGVCCAAARAATCA & \\
\hline
\end{tabular}

\subsection{Phylogenetic Analysis and Genetic Comparisons}

To establish phyletic positions of both new species, a phylogenetic tree was constructed using the dataset from Kaczmarek et al. [7] with the addition of sequences obtained in this study as well as sequences that were published to date (Table 2). DNA sequences of Macrobiotus kamilae Coughlan \& Stec, 2019 [20] and Macrobiotus hannae Nowak \& Stec, 2018 [42] were used as the outgroup. The sequences were aligned using the AUTO method (for COI and ITS-2) and the Q-INS-I method (for ribosomal markers: 18S rRNA and $28 \mathrm{~S}$ rRNA) of MAFFT version $7[43,44]$ and manually checked against non-conservative alignments in BioEdit. Then, the aligned sequences were trimmed to 1016 (18S rRNA), 811 (28S rRNA), 554 (ITS-2), and 658 (COI) bp and concatenated using SequenceMatrix [45]. Before partitioning, the concatenated alignment was divided into 6 data blocks constituting three separate blocks of ribosomal markers and three separate blocks of three codon positions in the COI dataset. Using PartitionFinder [46] under the Akaike Information Criterion (AIC), the best scheme of partitioning and substitution models were chosen for posterior phylogenetic analysis (SM.04). Bayesian inference (BI) marginal posterior probabilities were calculated for the concatenated (18S rRNA + 28S rRNA + ITS-2 + COI) dataset using MrBayes v3.2 [47]. Random starting trees were used, and the analysis was run for 10 million generations, sampling the Markov chain every 1000 generations. An average standard deviation of split frequencies of $<0.01$ was used as a guide to ensure the 
two independent analyses had converged. The program Tracer v1.6 [48] was then used to ensure Markov chains had reached stationarity, and to determine the correct 'burn-in' for the analysis, which was the first $10 \%$ of generations. The ESS values were greater than 200 and the consensus tree was obtained after summarising the resulting topologies and discarding the 'burn-in'. The consensus tree was viewed and visualised by FigTree v.1.4.3 available from http:/ / tree.bio.ed.ac.uk/software/figtree (accessed on 10 August 2018). Uncorrected pairwise distances were calculated using MEGA7 and are given in Supplementary Materials (SM.5).

Table 2. Sequences used for phylogenetic analysis and genetic comparisons (see Material and Methods section for details). Bold font indicates sequences obtained in this study.

\begin{tabular}{|c|c|c|c|c|c|}
\hline Species & 18S rRNA & 28S rRNA & ITS-2 & COI & Source \\
\hline M. ethiopicus Stec \& Kristensen, 2017 [49] & MF678793 & MF678792 & MN122776 & MF678794 & {$[15,49]$} \\
\hline M. datanlanicus Stec, 2019 [15] & MK584659 & MK584658 & MK584657 & MK578905 & [15] \\
\hline M. dilimanensis Itang et al., 2020 [50] & MN257048 & MN257049 & MN257050 & MN257047 & [50] \\
\hline M. philippinicus Mapalo et al., 2016 [30] & KX129793 & KX129794 & KX129795 & KX129796 & [30] \\
\hline M. insanis Mapalo et al., 2017 [51] & MF441488 & MF441489 & MF441490 & MF441491 & [51] \\
\hline M. hilariae Vecchi et al., 2016 [5] & KT226070 & & & KT226108 & [5] \\
\hline \multirow[t]{2}{*}{ M. radiatus (Pilato et al., 1991) [52] } & MH197153 & MH197152 & MH197267 & MH195147 & [53] \\
\hline & & & MH197268 & MH195148 & \\
\hline M. romani Roszkowska et al., 2018 [54] & MH197158 & MH197151 & MH197150 & MH195149 & [54] \\
\hline \multirow[t]{2}{*}{ M. harmsworthi (Murray, 1907) [17] } & MH197146 & MH197264 & MH197154 & MH195150 & [9] \\
\hline & & & & MH195151 & \\
\hline M. occultatus Kaczmarek et al., 2018 [9] & MH197147 & & MH197155 & MH195152 & [9] \\
\hline M. furciger group species NO & MH197148 & MH197265 & MH197156 & MH195153 & [9] \\
\hline M. harmsworthi group species RU & MH197149 & MH197266 & MH197157 & MH195154 & [9] \\
\hline \multirow[t]{3}{*}{ M. furciger (Murray, 1907) [55] } & & & & JX865306 & [56] \\
\hline & & & & JX865308 & \\
\hline & & & & JX865314 & \\
\hline M. fiedleri Kaczmarek et al., 2020 [7] & MH681585 & MH681693 & MH681724 & MH676056 & [7] \\
\hline "M. harmsworthi" & & & & GU113140 & $\begin{array}{r}\text { Li and Xiao } \\
\text { (unpublished) }\end{array}$ \\
\hline M. anastasiae Tumanov, 2020 [8] & MT903468 & MT903612 & MT903470 & MT904513 & [8] \\
\hline M. skoracki Kaczmarek et al., 2018 [9] & & MW680636 & & MW656257 & [57] \\
\hline \multirow[t]{2}{*}{ M. imperialissp. nov. } & OL257854 & OL257866 & & OL311514 & this study \\
\hline & OL257855 & OL257867 & & OL311515 & this study \\
\hline \multirow[t]{3}{*}{ M. marmoreussp. nov. } & OL257856 & OL257868 & OL257861 & OL311516 & this study \\
\hline & OL257857 & OL257869 & OL257862 & OL311517 & this study \\
\hline & OL257858 & OL257870 & OL257863 & OL311518 & this study \\
\hline M. cf. barabanovi & MN310392 & MN310388 & MN310390 & MN313170 & [7] \\
\hline \multirow[t]{2}{*}{ Macrobiotus kamilae Coughlan \& Stec, 2019 [20] } & MK737070 & MK737064 & MK737067 & MK737920 & [20] \\
\hline & & & & MK737921 & \\
\hline Macrobiotus hannae Nowak \& Stec, 2018 [42] & MH063922 & МH063924 & MH063923 & MH057764 & [42] \\
\hline
\end{tabular}

\section{Results}

3.1. Taxonomic Account of the New Species

Phylum: Tardigrada Doyère, 1840 [58].

Class: Eutardigrada Richters, 1926 [59].

Order: Parachela Schuster, Nelson, Grigarick \& Christenberry, 1980 [60].

Superfamily: Macrobiotoidea Thulin, 1928 [61] (in [62]).

Family: Macrobiotidae Thulin, 1928 [61].

Genus: Mesobiotus Vecchi, Cesari, Bertolani, Jönsson, Rebecchi \& Guidetti, 2016 [5].

\subsection{Description of the New Species}

Mesobiotus imperialis sp. nov.

ZooBank: urn:lsid:zoobank.org:act:6ABF8C3D-FDD1-4DE0-88C8-54F49E21EFB4 
(Tables 3 and 4, Figures 1-6).

Table 3. Measurements [in $\mu \mathrm{m}$ ] and $p t$ values of selected morphological structures of animals of Mesobiotus imperialis sp. nov.; specimens mounted in Hoyer's medium; N-number of specimen/structures measured, RANGE refers to the smallest and the largest structure among all measured specimens; SD—standard deviation.

\begin{tabular}{|c|c|c|c|c|c|c|c|c|c|c|c|c|c|}
\hline \multirow[t]{2}{*}{ CHARACTER } & \multirow[t]{2}{*}{$\mathbf{N}$} & \multicolumn{6}{|c|}{ RANGE } & \multicolumn{2}{|c|}{ Mean } & \multicolumn{2}{|c|}{ SD } & \multicolumn{2}{|c|}{ Holotype } \\
\hline & & \multicolumn{3}{|c|}{$\mu \mathbf{m}$} & \multicolumn{3}{|c|}{$p t$} & \multirow{3}{*}{$\begin{array}{l}\mu \mathrm{m} \\
389\end{array}$} & \multirow{3}{*}{$\frac{p t}{1012}$} & \multirow{3}{*}{$\begin{array}{c}\mu \mathrm{m} \\
51\end{array}$} & \multirow{3}{*}{$\begin{array}{l}p t \\
75\end{array}$} & \multirow{2}{*}{$\frac{\mu \mathrm{m}}{436}$} & \multirow{2}{*}{$\frac{p t}{1053}$} \\
\hline Body length & 20 & 313 & - & 539 & 895 & - & 1219 & & & & & & \\
\hline Buccal tube & & & & & & & & & & & & & \\
\hline Buccal tube length & 20 & 30.5 & - & 44.2 & & - & & 38.4 & - & 3.4 & - & 41.4 & - \\
\hline Stylet support insertion point & 20 & 22.9 & - & 34.1 & 75.0 & - & 77.3 & 29.2 & 76.0 & 2.7 & 0.8 & 31.2 & 75.4 \\
\hline Buccal tube external width & 20 & 5.2 & - & 7.6 & 15.7 & - & 18.1 & 6.5 & 16.8 & 0.6 & 0.6 & 7.0 & 16.9 \\
\hline Buccal tube internal width & 20 & 4.0 & - & 5.7 & 10.8 & - & 13.8 & 4.9 & 12.6 & 0.5 & 0.7 & 5.7 & 13.8 \\
\hline Ventral lamina length & 20 & 19.9 & - & 27.0 & 56.2 & - & 65.2 & 23.2 & 60.4 & 1.8 & 2.2 & 23.6 & 57.0 \\
\hline \multicolumn{14}{|l|}{ Placoid lengths } \\
\hline Macroplacoid 1 & 20 & 3.8 & - & 6.0 & 11.7 & - & 14.4 & 5.1 & 13.4 & 0.6 & 0.9 & 5.6 & 13.5 \\
\hline Macroplacoid 2 & 20 & 2.9 & - & 4.5 & 7.7 & - & 11.3 & 3.7 & 9.7 & 0.5 & 0.9 & 4.2 & 10.1 \\
\hline Macroplacoid 3 & 20 & 3.1 & - & 5.8 & 10.2 & - & 13.1 & 4.5 & 11.6 & 0.6 & 0.8 & 4.7 & 11.4 \\
\hline Microplacoid & 20 & 3.2 & - & 5.2 & 8.3 & - & 12.7 & 4.1 & 10.7 & 0.5 & 1.1 & 4.2 & 10.1 \\
\hline Macroplacoid row & 20 & 11.9 & - & 19.4 & 38.6 & - & 43.9 & 16.0 & 41.5 & 1.8 & 1.6 & 17.9 & 43.2 \\
\hline Placoid row & 20 & 16.0 & - & 25.7 & 52.0 & - & 58.5 & 21.3 & 55.4 & 2.4 & 2.2 & 23.8 & 57.5 \\
\hline \multicolumn{14}{|l|}{ Claw I heights } \\
\hline External primary branch & 20 & 7.5 & - & 10.6 & 20.7 & - & 25.6 & 8.7 & 22.8 & 0.8 & 1.4 & 9.6 & 23.2 \\
\hline External secondary branch & 18 & 6.4 & - & 8.5 & 17.2 & - & 22.3 & 7.3 & 19.0 & 0.7 & 1.5 & 7.9 & 19.1 \\
\hline Internal primary branch & 20 & 6.7 & - & 10.0 & 19.7 & - & 22.6 & 8.2 & 21.2 & 0.9 & 0.9 & 9.2 & 22.2 \\
\hline Internal secondary branch & 18 & 5.1 & - & 8.0 & 15.8 & - & 19.2 & 6.7 & 17.3 & 0.7 & 1.1 & 7.4 & 17.9 \\
\hline \multicolumn{14}{|l|}{ Claw II heights } \\
\hline External primary branch & 20 & 7.3 & - & 11.1 & 22.3 & - & 26.0 & 9.2 & 24.0 & 0.9 & 1.0 & 10.3 & 24.9 \\
\hline External secondary branch & 18 & 6.6 & - & 8.8 & 17.6 & - & 22.9 & 7.6 & 19.9 & 0.7 & 1.5 & 7.3 & 17.6 \\
\hline Internal primary branch & 20 & 7.2 & - & 9.6 & 19.2 & - & 23.6 & 8.1 & 21.2 & 0.7 & 1.2 & 8.6 & 20.8 \\
\hline Internal secondary branch & 13 & 6.1 & - & 8.0 & 16.4 & - & 20.3 & 7.1 & 18.4 & 0.6 & 1.4 & 7.1 & 17.1 \\
\hline \multicolumn{14}{|l|}{ Claw III heights } \\
\hline External primary branch & 20 & 7.8 & - & 11.1 & 21.4 & - & 27.9 & 9.3 & 24.2 & 0.9 & 1.6 & 10.4 & 25.1 \\
\hline External secondary branch & 18 & 6.4 & - & 8.8 & 17.2 & - & 23.1 & 7.6 & 19.8 & 0.7 & 1.6 & 8.8 & 21.3 \\
\hline Internal primary branch & 19 & 6.0 & - & 9.7 & 16.2 & - & 23.3 & 8.0 & 20.9 & 1.0 & 1.6 & 8.5 & 20.5 \\
\hline Internal secondary branch & 15 & 5.9 & - & 8.1 & 16.9 & - & 20.8 & 7.1 & 18.3 & 0.7 & 1.1 & 8.0 & 19.3 \\
\hline \multicolumn{14}{|l|}{ Claw IV heights } \\
\hline Anterior primary branch & 20 & 8.0 & - & 11.2 & 23.4 & - & 28.2 & 9.7 & 25.3 & 0.9 & 1.2 & 10.8 & 26.1 \\
\hline Anterior secondary branch & 18 & 6.5 & - & 8.8 & 17.9 & - & 22.1 & 7.8 & 20.3 & 0.7 & 1.1 & 8.5 & 20.5 \\
\hline Posterior primary branch & 20 & 8.5 & - & 12.1 & 25.0 & - & 30.1 & 10.3 & 27.0 & 0.9 & 1.2 & 11.0 & 26.6 \\
\hline Posterior secondary branch & 9 & 7.7 & - & 9.3 & 20.2 & - & 22.1 & 8.3 & 21.2 & 0.5 & 0.7 & $?$ & $?$ \\
\hline
\end{tabular}

Table 4. Measurements [in $\mu \mathrm{m}$ ] of the eggs of Mesobiotus imperialis sp. nov.; eggs mounted in Hoyer's medium; process base/height ratio is expressed as percentage; $\mathrm{N}$-number of eggs/structures measured, RANGE refers to the smallest and the largest structure among all measured specimens; SD—standard deviation.

\begin{tabular}{|c|c|c|c|c|c|c|}
\hline Character & $\mathbf{N}$ & & RANGE & & Mean & SD \\
\hline Egg bare diameter & 20 & 53.9 & - & 70.2 & 62.8 & 4.0 \\
\hline Egg full diameter & 20 & 74.7 & - & 94.6 & 85.7 & 4.9 \\
\hline Process height & 60 & 8.3 & - & 15.3 & 11.9 & 1.3 \\
\hline Process base width & 60 & 6.9 & - & 12.5 & 10.0 & 1.1 \\
\hline Process base/height ratio & 60 & $65 \%$ & - & $116 \%$ & $85 \%$ & $11 \%$ \\
\hline Inter-process distance & 60 & 1.7 & - & 3.9 & 2.7 & 0.5 \\
\hline $\begin{array}{l}\text { Number of processes on the egg } \\
\text { circumference }\end{array}$ & 20 & 15 & - & 18 & 16.2 & 0.8 \\
\hline
\end{tabular}




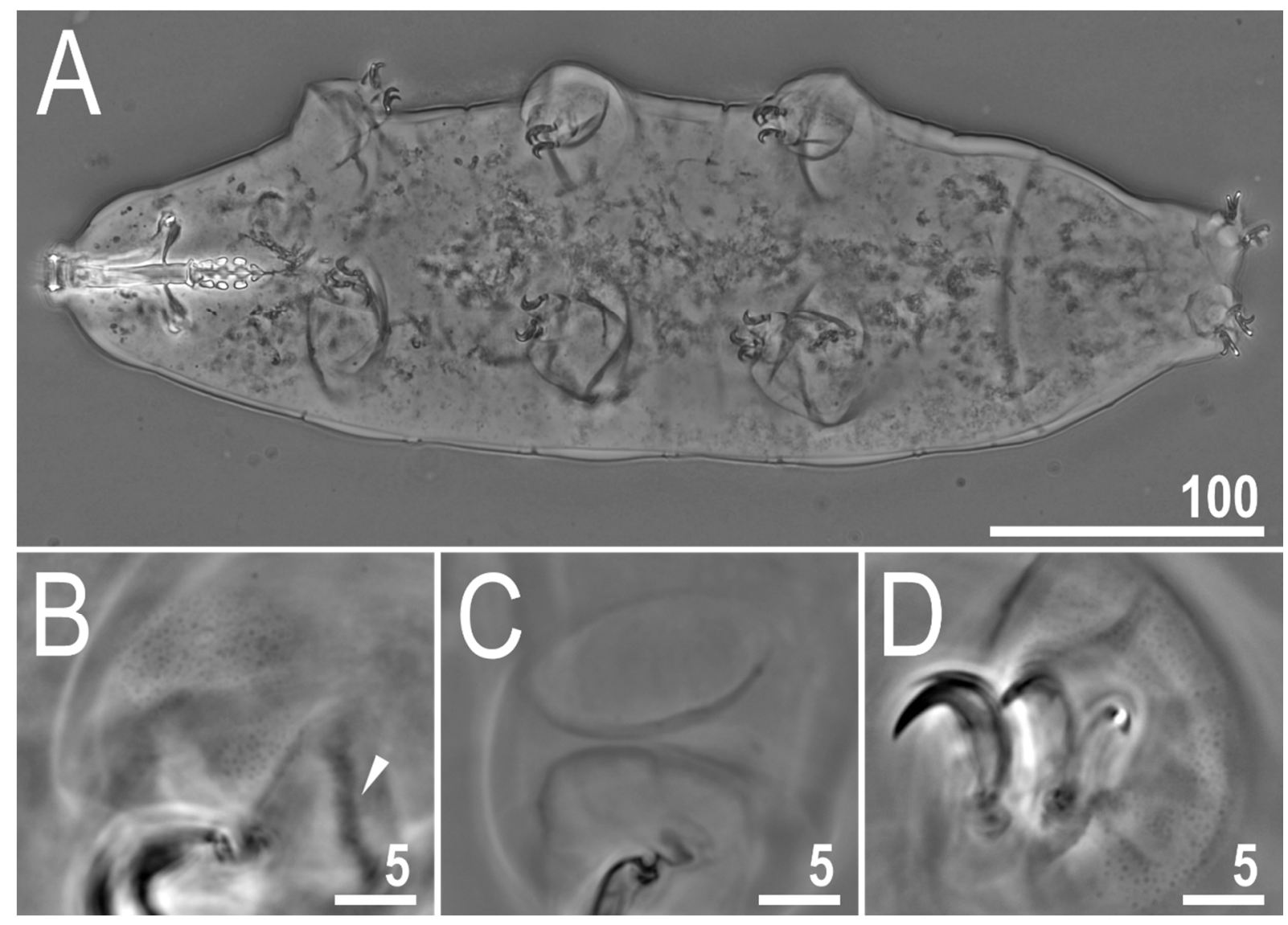

Figure 1. Mesobiotus imperialis sp. nov.-PCM image of habitus and leg's cuticle morphology: (A)—dorso-ventral projection (holotype); (B)—granulation on the external surface of leg II (holotype); (C)-a pulvinus-like cuticular bulge on the internal surface of leg III (paratype); (D)_granulation on dorsal and lateral surface of leg IV (paratype). Filled flat arrowhead indicates a single continuous cuticular bar above the claws. Scale bar in $\mu \mathrm{m}$.
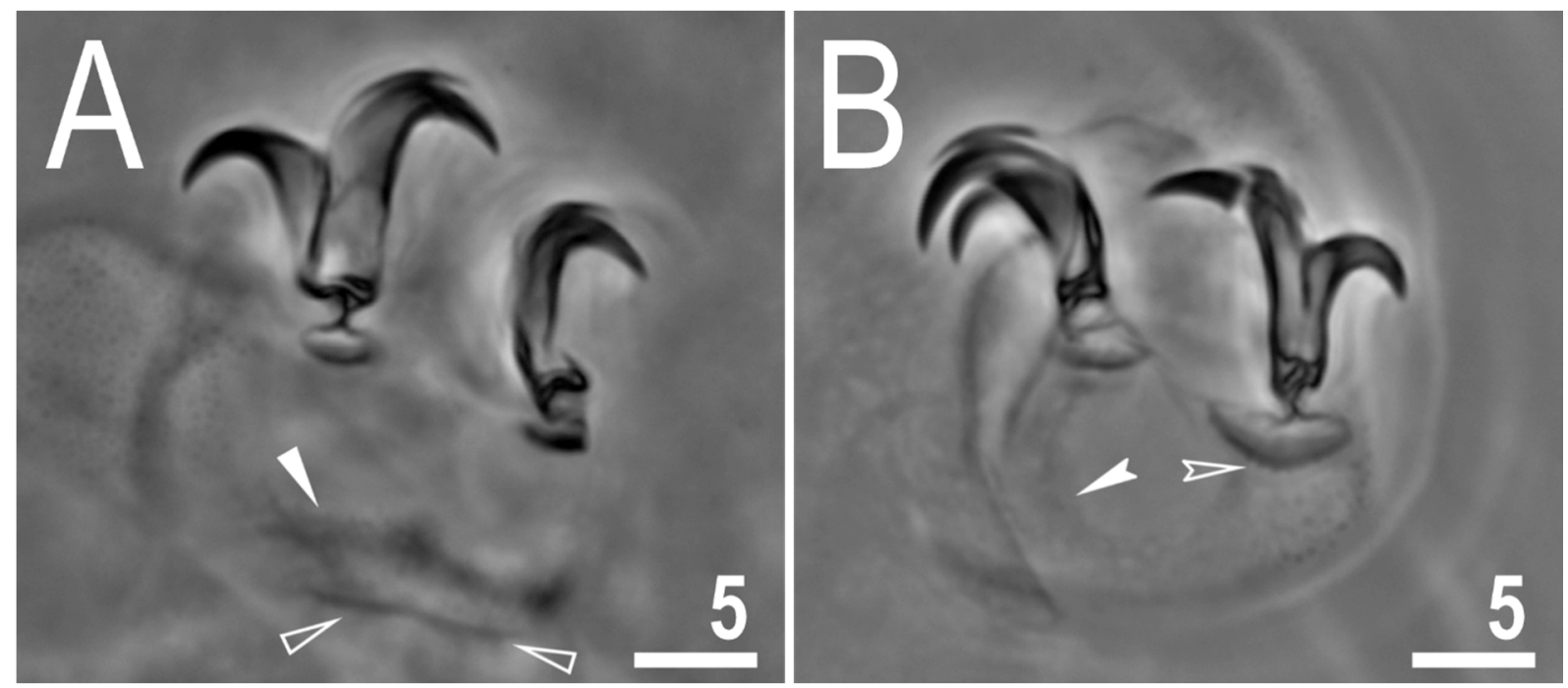

Figure 2. Mesobiotus imperialis sp. nov._PCM images of claws: (A)—claw III with smooth lunulae (holotype); (B)—claw IV with smooth lunulae (paratype). Filled flat arrowhead indicates a single continuous cuticular bar above the claws, empty flat arrowheads indicate paired muscles attachments, filled indented arrowhead indicates horseshoe structure connecting the anterior and the posterior claw, empty indented arrowheads indicate faint dentation in lunula IV. Scale bars in $\mu \mathrm{m}$. 

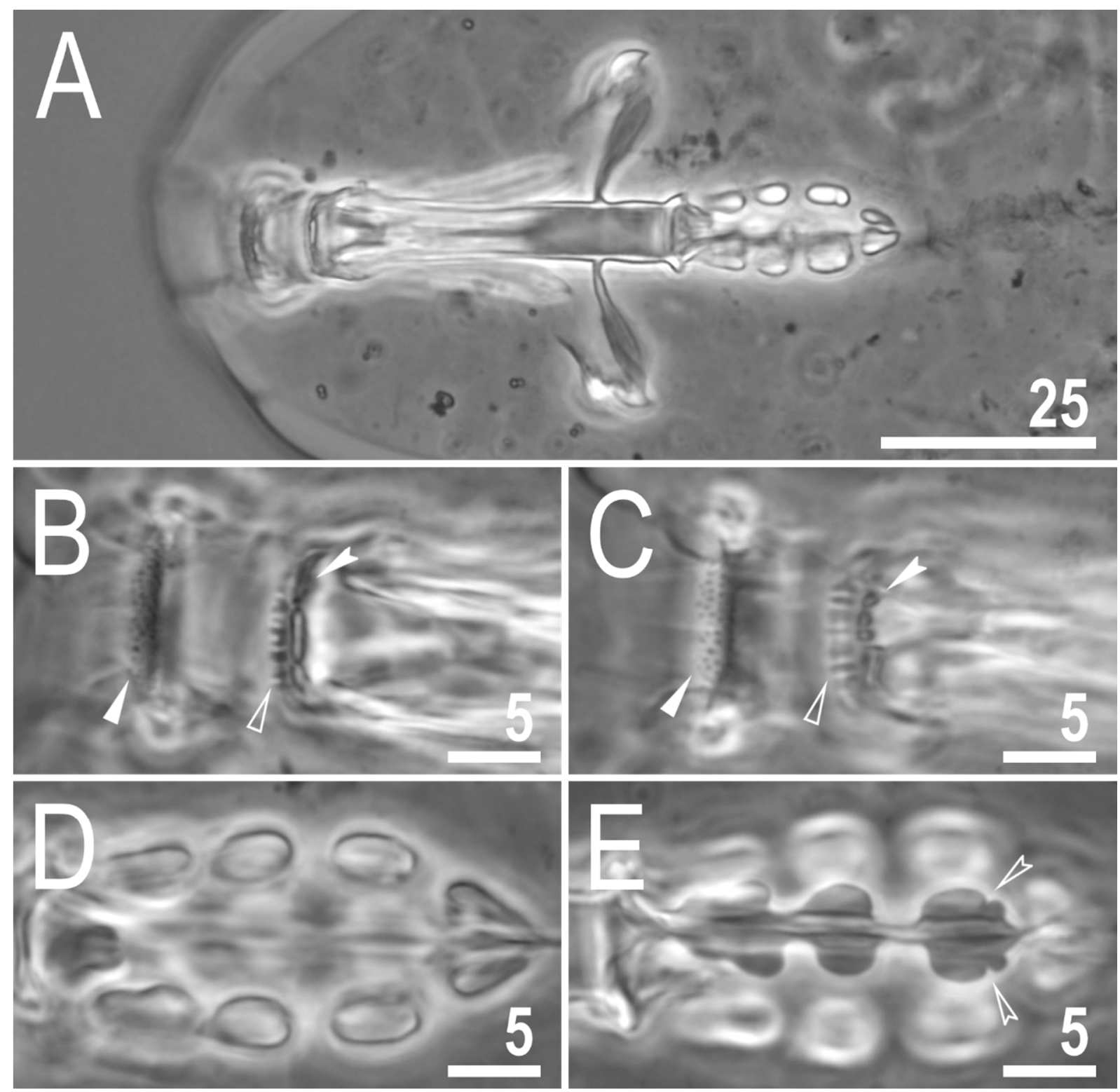

Figure 3. Mesobiotus imperialis sp. nov.-PCM images of the buccal apparatus: (A) —an entire buccal apparatus (paratype); (B,C) - the oral cavity armature, dorsal and ventral teeth, respectively (paratype); (D,E)—placoid morphology, dorsal and ventral placoids, respectively (holotype). Filled flat arrowheads indicate the first band of teeth, empty flat arrowheads indicate the second band of teeth, filled indented arrowheads indicate the third band of teeth, empty indented arrowheads indicate subterminal constrictions in the third macroplacoid. Scale bars in $\mu \mathrm{m}$. 

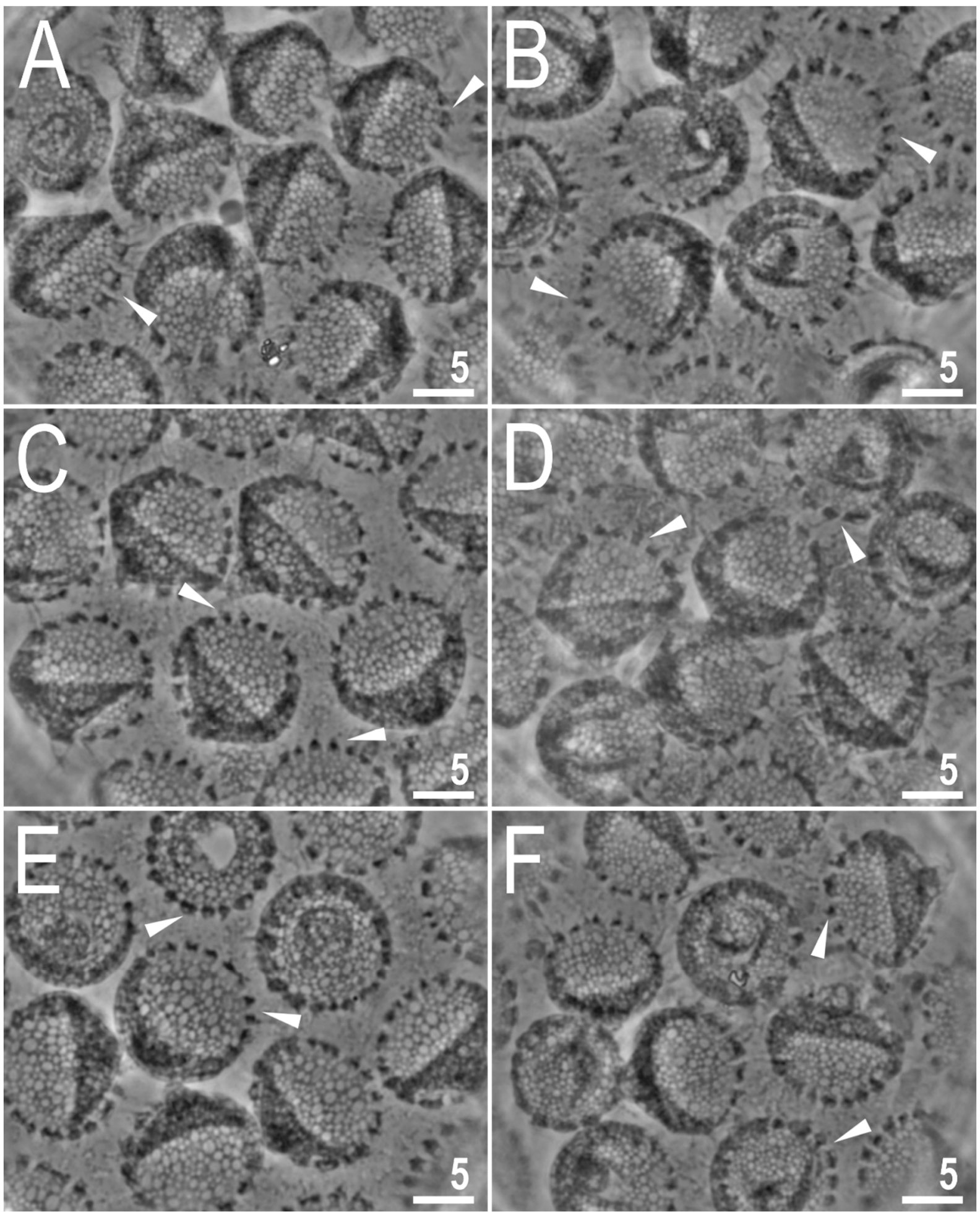

Figure 4. Mesobiotus imperialis sp. nov.-PCM images of the egg surface under $\times 1000$ magnification. Arrowheads indicate crowns of strong thickenings around the process bases. Scale bars in $\mu \mathrm{m}$. 

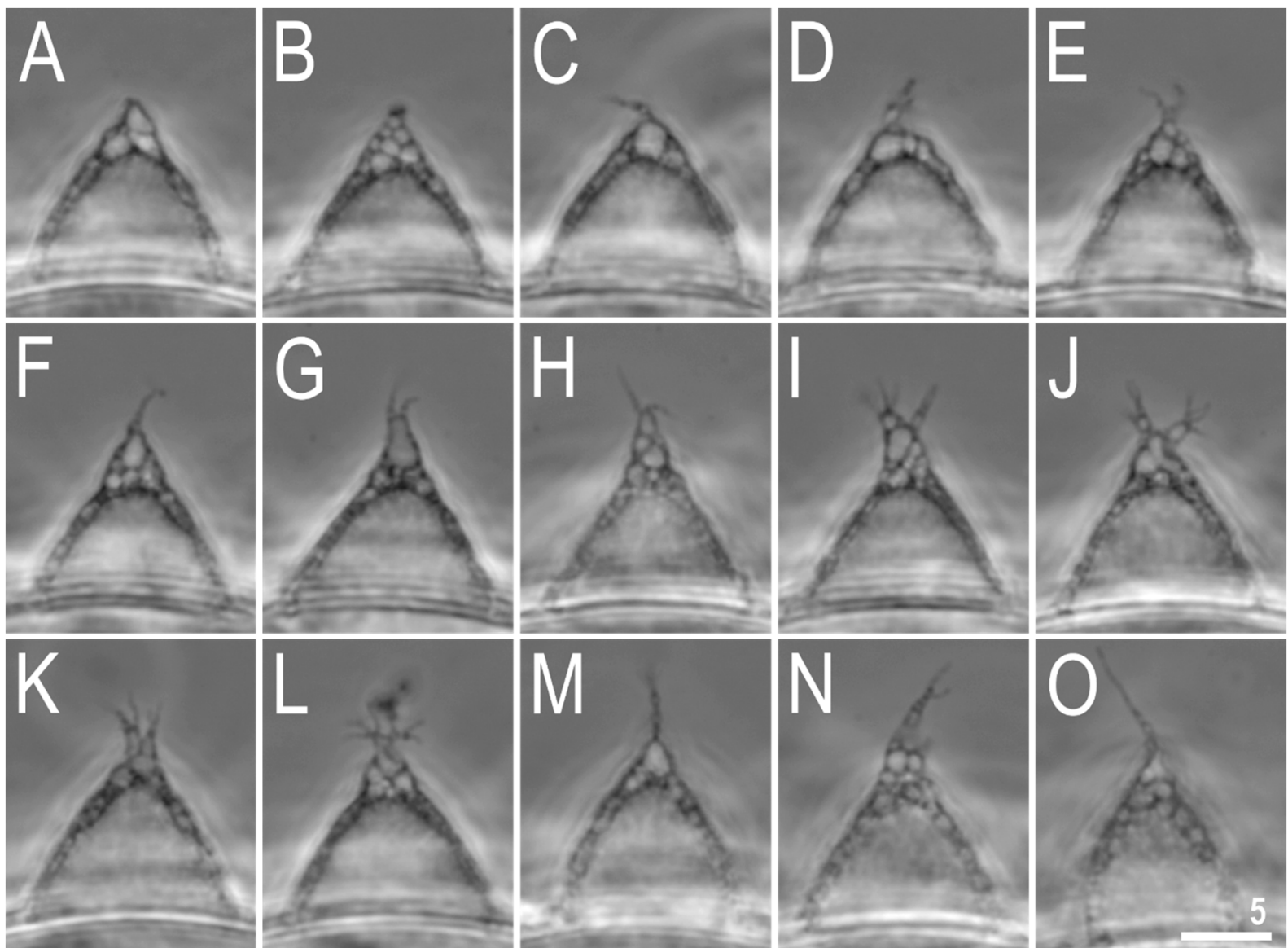

Figure 5. Mesobiotus imperialis sp. nov.-PCM images of the egg processes midsections under $\times 1000$ magnification. Scale bar in $\mu \mathrm{m}$.

\subsubsection{Material Examined}

In total, 73 animals, 50 eggs mounted on microscope slides in Hoyer's medium (some of the eggs were embryonated), 5 eggs fixed on a SEM stub (19.14) and 2 specimens were processed for DNA sequencing.

\subsubsection{Type Locality}

$16^{\circ} 28^{\prime} 04^{\prime \prime}$ N, $107^{\circ} 34^{\prime} 37^{\prime \prime}$ E; 6 m asl: Vietnam, Huế, Imperial City, Kiến Trung Palace (Điện Kiến Trung), bark of a dying tree near a pat walk, coll. Daniel Stec and Krzysztof Miler, August 2018.

\subsubsection{Etymology}

The species is named after the place where it was discovered. Namely, it is Imperial City, a walled enclosure within the citadel of the city of Huê and the former imperial capital of Vietnam.

\subsubsection{Type Depositories}

The holotype with 6 paratypes (slide VN.061.03) and 47 paratypes (slides: VN.061.*, where the asterisk can be substituted by any of the following numbers: 01-02, 04-09) and 26 eggs (slides: VN.061.*: 12-15) are deposited at the Institute of Systematics and Evolution of Animals, Polish Academy of Sciences, Sławkowska 17, 31-016, Kraków, Poland;

Nineteen paratypes (slides: VN.061.*: 10-11), 24 eggs (slides: VN.061.*: 16-17) and SEM stub: 19.14 are deposited at the Institute of Zoology and Biomedical Research, Jagiellonian University, Gronostajowa 9, 30-387, Kraków, Poland. 

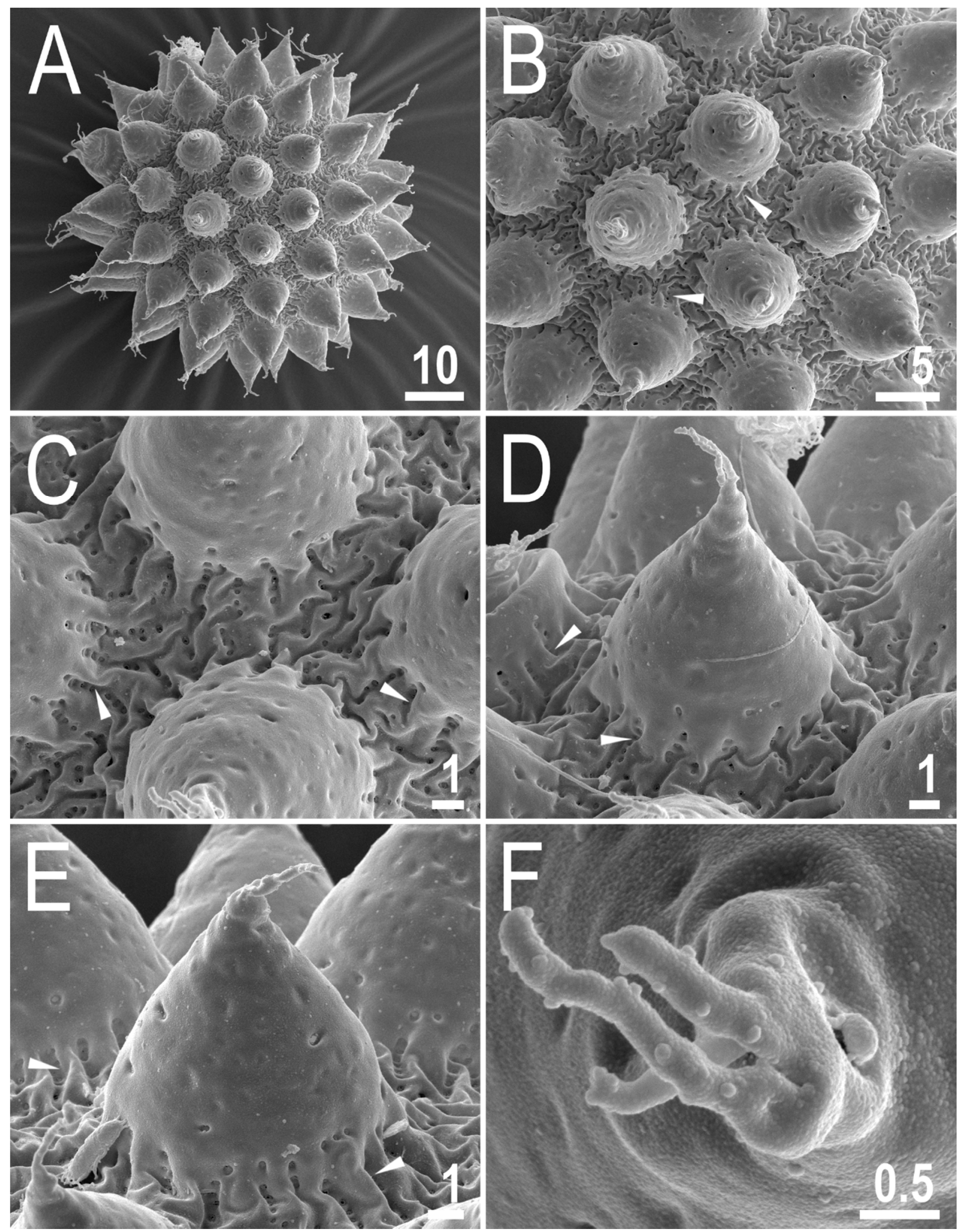

Figure 6. Mesobiotus imperialis sp. nov.—SEM images of eggs: (A)—entire view of the egg; $(\mathbf{B}, \mathbf{C})$ - details of the egg surface between processes; $(\mathbf{D}, \mathbf{E})$ — egg processes; (F) — top part of the processes divided into several flexible filaments covered with fine granulation. Arrowheads indicate strong thickenings around the process bases. Scale bars in $\mu \mathrm{m}$. 


\subsubsection{Animals}

The body is almost transparent in small specimens and whitish in adults; after fixation in Hoyer's medium, the body is transparent (Figure 1A). Eyes are present in alive animals and dissolved by Hoyer's medium in about $50 \%$ of all mounted specimens. The body cuticle is smooth, i.e., without pores or sculpturing. Fine granulation is present on the external surface of all legs I-III (Figure 1B) as well as on the lateral and dorsal surfaces of legs IV (Figure 1D). A cuticular bulge/fold, resembling a pulvinus, is present on the internal surface of legs I-III (Figure 1C). Claws of the Mesobiotus type were observed, with a peduncle connecting the claw to the lunula, a basal septum and well-developed accessory points situated in parallel to the primary branch (Figure 2A,B). Lunulae under claws I-III are smooth (Figure 2A) and those under claws IV are slightly dentate (Figure 2B; a character visible in about $50 \%$ of specimens mounted in Hoyer's medium). A single continuous cuticular bar and double muscle attachments are present above claws I-III (Figures 1B and 2A), whereas a horseshoe-shaped structure connects the anterior and posterior lunulae on claws IV (Figure 2B).

The mouth is antero-ventral. The Bucco-pharyngeal apparatus is of the Macrobiotus type, with the ventral lamina and ten small peribuccal lamellae (Figure 3A). The oral cavity armature is well developed and is composed of three bands of teeth (Figure 3B,C). The first band of teeth is composed of numerous small granules arranged in several discrete rows situated anteriorly in the oral cavity, just behind the bases of the peribuccal lamellae (Figure 3B,C). The second band of teeth is situated between the ring fold and the third band of teeth and is composed of ridges parallel to the main axis of the buccal tube that are larger than those in the first band (Figure 3B,C). The teeth of the third band are located within the posterior portion of the oral cavity, between the second band of teeth and the buccal tube opening (Figure 3B,C). The third band of teeth is discontinuous and divided into dorsal and ventral portions. Under PCM, dorsal teeth are visible as two lateral and one median transverse ridges/crests (Figure 3B) whereas ventral teeth consist of two lateral transverse ridges / crests, between which two to four (usually three) roundish and separated ventro-median teeth are present (Figure 3C). The pharyngeal bulb is ovoid (Figure 3A), with triangular apophyses, three rod-shaped macroplacoids and a large, elongated drop-shaped microplacoid placed close to the third macroplacoid (Figure 3D,E). The macroplacoid length sequence is $2<3<1$. The first macroplacoid is anteriorly narrowed and the third has a clearly defined sub-terminal constriction (Figure 3E). Measurements and statistics are presented in Table 3.

\subsubsection{Eggs}

Eggs are white, laid free, spherical in shape and equipped with conical processes (Figures 4-6). In PCM, the egg surface between processes seems to be rough with both dark and faintly light refracting dots (Figure 4), whereas in SEM, the surface is clearly wrinkled, with wrinkles radiating out from the process bases but not forming a connective network (Figure 6A-E). Small pores (up to $0.3 \mu \mathrm{m}$ ) are scattered across the inter-process surface with their lumen often being covered by a reticulate internal structure that seems to be a remnant of the reduced labyrinthine layer. The pores are clearly visible in SEM (Figure 6A-E), but under PCM, they are most probably seen as the mentioned faintly light refracting dots (Figure 4). The bases of egg processes are surrounded by crowns of strong thickenings that are evident in PCM as well as SEM (Figures 4 and 6A-E). The egg processes are evenly spaced, with a flexible upper portion often equipped with shorter flexible filaments (Figure 5). This flexible portion of the processes seems to be fragile and susceptible to fracture (Figure $5 \mathrm{~A}-\mathrm{C}$ ). Often, in the upper portion of the egg processes, below the flexible part, a bubble-like structure is present and visible in the process midsection (Figure 5). The labyrinthine layer is visible under PCM as a reticulum in process walls, with varying mesh sizes uniformly distributed within the process walls (Figure 4). In SEM, the process walls are smooth with unevenly distributed depressions and faint tubercles and occasionally also pores often with closed lumen (Figure 6A-E). The top flexible portions of egg processes 
are irregularly covered with small granules that are visible only in SEM (Figure 6D,F). Measurements and statistics are presented in Table 4.

\subsubsection{Reproduction}

The examination of all individuals, freshly mounted in Hoyer's medium, under PCM did not reveal any testis or spermathecae filled with spermatozoa. Thus, it is most likely that the new species is parthenogenetic.

\subsubsection{DNA sequences}

The obtained sequences for three molecular markers analysed in this study were of good quality and were represented by single haplotypes. However, several attempts to amplify the ITS- 2 marker for the new species failed, preventing me from obtaining these sequences for the new species.

The 18S rRNA sequences (GenBank: OL257854-5), 1008 bp long.

The $28 \mathrm{~S}$ rRNA sequences (GenBank: OL257866-7), 774 bp long.

The COI sequences (GenBank: OL311514-5), 658 bp long.

\subsection{Description of the New Species}

Mesobiotus marmoreus sp. nov.

ZooBank: urn:lsid:zoobank.org:act:26C5E830-9A84-4019-B3A4-301339FE3220

(Tables 5 and 6, Figures 7-11).

Table 5. Measurements [in $\mu \mathrm{m}$ ] and $p t$ values of selected morphological structures of animals of Mesobiotus marmoreus sp. nov.; specimens mounted in Hoyer's medium; N-number of specimen/structures measured, RANGE refers to the smallest and the largest structure among all measured specimens; SD—standard deviation.

\begin{tabular}{|c|c|c|c|c|c|c|c|c|c|c|c|c|c|}
\hline \multirow[t]{2}{*}{ Character } & \multirow[t]{2}{*}{$\mathbf{N}$} & \multicolumn{6}{|c|}{ RANGE } & \multicolumn{2}{|c|}{ Mean } & \multicolumn{2}{|c|}{ SD } & \multicolumn{2}{|c|}{ Holotype } \\
\hline & & & $\mu \mathrm{m}$ & & & $p t$ & & $\mu \mathrm{m}$ & $p t$ & $\mu \mathrm{m}$ & $p t$ & $\mu \mathrm{m}$ & $p t$ \\
\hline Body length & 20 & 234 & - & 372 & 883 & - & 1042 & 320 & 970 & 32 & 48 & 308 & 982 \\
\hline \multicolumn{14}{|l|}{ Buccal tube } \\
\hline Buccal tube length & 20 & 26.5 & - & 37.1 & & - & & 33.0 & - & 2.7 & - & 31.3 & - \\
\hline Stylet support insertion point & 20 & 20.2 & - & 28.7 & 76.2 & - & 77.8 & 25.5 & 77.1 & 2.2 & 0.5 & 24.0 & 76.7 \\
\hline Buccal tube external width & 20 & 4.5 & - & 6.4 & 16.2 & - & 18.4 & 5.6 & 17.0 & 0.5 & 0.6 & 5.3 & 16.9 \\
\hline Buccal tube internal width & 20 & 3.2 & - & 4.9 & 12.0 & - & 14.6 & 4.2 & 12.7 & 0.4 & 0.6 & 3.9 & 12.5 \\
\hline Ventral lamina length & 20 & 15.9 & - & 22.5 & 57.9 & - & 62.5 & 19.9 & 60.2 & 1.6 & 1.1 & 19.2 & 61.3 \\
\hline \multicolumn{14}{|l|}{ Placoid lengths } \\
\hline Macroplacoid 1 & 20 & 3.6 & - & 6.1 & 12.9 & - & 16.4 & 4.8 & 14.6 & 0.6 & 0.9 & 4.2 & 13.4 \\
\hline Macroplacoid 2 & 20 & 2.3 & - & 3.8 & 8.5 & - & 10.8 & 3.2 & 9.6 & 0.4 & 0.6 & 3.0 & 9.6 \\
\hline Macroplacoid 3 & 20 & 3.2 & - & 5.0 & 10.6 & - & 13.6 & 4.0 & 12.0 & 0.6 & 1.1 & 3.4 & 10.9 \\
\hline Microplacoid & 20 & 3.0 & - & 4.7 & 9.6 & - & 12.7 & 3.6 & 10.9 & 0.4 & 0.8 & 3.5 & 11.2 \\
\hline Macroplacoid row & 20 & 11.1 & - & 16.9 & 38.9 & - & 45.6 & 14.0 & 42.4 & 1.5 & 1.6 & 12.6 & 40.3 \\
\hline Placoid row & 20 & 15.0 & - & 22.7 & 53.7 & - & 61.2 & 18.8 & 56.7 & 1.9 & 1.8 & 17.3 & 55.3 \\
\hline \multicolumn{14}{|l|}{ Claw I heights } \\
\hline External primary branch & 20 & 6.4 & - & 8.6 & 19.5 & - & 25.4 & 7.6 & 23.0 & 0.6 & 1.5 & 7.7 & 24.6 \\
\hline External secondary branch & 16 & 5.1 & - & 7.6 & 15.5 & - & 20.9 & 6.3 & 18.9 & 0.6 & 1.4 & 6.2 & 19.8 \\
\hline Internal primary branch & 20 & 6.2 & - & 8.4 & 18.9 & - & 24.2 & 7.3 & 22.1 & 0.6 & 1.4 & 6.8 & 21.7 \\
\hline Internal secondary branch & 15 & 5.0 & - & 7.1 & 14.3 & - & 19.6 & 6.1 & 18.0 & 0.6 & 1.3 & 5.6 & 17.9 \\
\hline \multicolumn{14}{|l|}{ Claw II heights } \\
\hline External primary branch & 20 & 7.0 & - & 8.8 & 21.0 & - & 26.6 & 8.0 & 24.3 & 0.5 & 1.5 & 7.9 & 25.2 \\
\hline External secondary branch & 18 & 5.3 & - & 7.6 & 16.2 & - & 21.7 & 6.5 & 19.5 & 0.5 & 1.3 & 6.8 & 21.7 \\
\hline Internal primary branch & 20 & 6.2 & - & 8.9 & 19.2 & - & 24.5 & 7.3 & 22.1 & 0.6 & 1.5 & 7.1 & 22.7 \\
\hline Internal secondary branch & 19 & 5.0 & - & 7.0 & 16.3 & - & 20.1 & 6.1 & 18.6 & 0.5 & 1.2 & 6.3 & 20.1 \\
\hline \multicolumn{14}{|l|}{ Claw III heights } \\
\hline External primary branch & 20 & 7.5 & - & 9.8 & 21.5 & - & 28.3 & 8.2 & 24.9 & 0.6 & 1.7 & 8.2 & 26.2 \\
\hline External secondary branch & 15 & 5.8 & - & 7.6 & 16.6 & - & 22.6 & 6.6 & 20.1 & 0.6 & 1.4 & 6.8 & 21.7 \\
\hline Internal primary branch & 20 & 6.4 & - & 8.8 & 19.8 & - & 25.7 & 7.5 & 22.6 & 0.6 & 1.6 & 7.0 & 22.4 \\
\hline Internal secondary branch & 17 & 5.3 & - & 7.4 & 16.2 & - & 20.9 & 6.1 & 18.7 & 0.6 & 1.3 & 6.2 & 19.8 \\
\hline
\end{tabular}


Table 5. Cont.

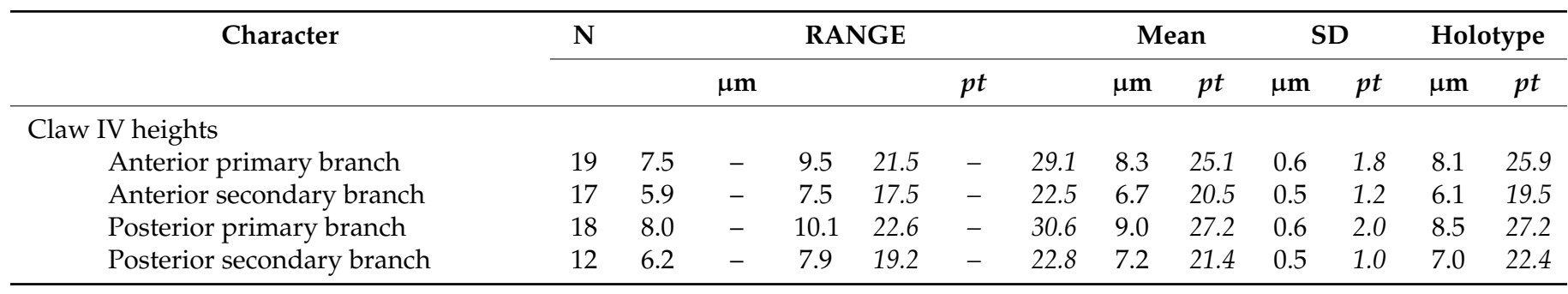

Table 6. Measurements [in $\mu \mathrm{m}$ ] of the eggs of Mesobiotus marmoreus sp. nov.; eggs mounted in Hoyer's medium; process base/height ratio is expressed as percentage; $\mathrm{N}$-number of eggs/structures measured, RANGE refers to the smallest and the largest structure among all measured specimens; SD—standard deviation.

\begin{tabular}{|c|c|c|c|c|c|c|}
\hline Character & $\mathbf{N}$ & & RANGE & & Mean & SD \\
\hline Egg bare diameter & 7 & 63.4 & - & 69.6 & 67.0 & 2.4 \\
\hline Egg full diameter & 7 & 77.9 & - & 82.2 & 80.0 & 1.4 \\
\hline Process height & 27 & 5.6 & - & 8.8 & 6.9 & 0.9 \\
\hline Process base width & 27 & 3.4 & - & 6.5 & 5.0 & 0.7 \\
\hline Process base/height ratio & 27 & $59 \%$ & - & $94 \%$ & $73 \%$ & $10 \%$ \\
\hline Inter-process distance & 27 & 1.5 & - & 3.3 & 2.3 & 0.4 \\
\hline $\begin{array}{l}\text { Number of processes on the egg } \\
\text { circumference }\end{array}$ & 7 & 26 & - & 30 & 28.3 & 1.5 \\
\hline
\end{tabular}

\subsubsection{Material Examined}

In total, 53 animals, 9 eggs mounted on microscope slides in Hoyer's medium (some of the eggs were embryonated), 4 eggs fixed on an SEM stub (18.09) and 3 specimens were processed for DNA sequencing.

\subsubsection{Type Locality}

$16^{\circ} 00^{\prime} 14^{\prime \prime} \mathrm{N}, 108^{\circ} 15^{\prime} 48^{\prime \prime} \mathrm{E} ; 66 \mathrm{~m}$ asl: Vietnam, The Marble Mountains, south of Đà Nẵng, stone walkway, coll. Daniel Stec and Krzysztof Miler, August 2018.

\subsubsection{Etymology}

The species is named after the place where it was discovered, namely, The Marble Mountains, from Latin "marble" = "marmor".

\subsubsection{Type Depositories}

The holotype with 7 paratypes (slide VN.055.06) and 27 paratypes (slides: VN.055.*, where the asterisk can be substituted by any of the following numbers: 05, 07-08) and 7 eggs (slides: VN.055.*: 01-02) are deposited at the Institute of Systematics and Evolution of Animals, Polish Academy of Sciences, Sławkowska 17, 31-016, Kraków, Poland;

Eighteen paratypes (slides: VN.055.*: 09-10), two eggs (slides: VN.055.*: 03-04) and an SEM stub: 18.09 are deposited at the Institute of Zoology and Biomedical Research, Jagiellonian University, Gronostajowa 9, 30-387, Kraków, Poland. 

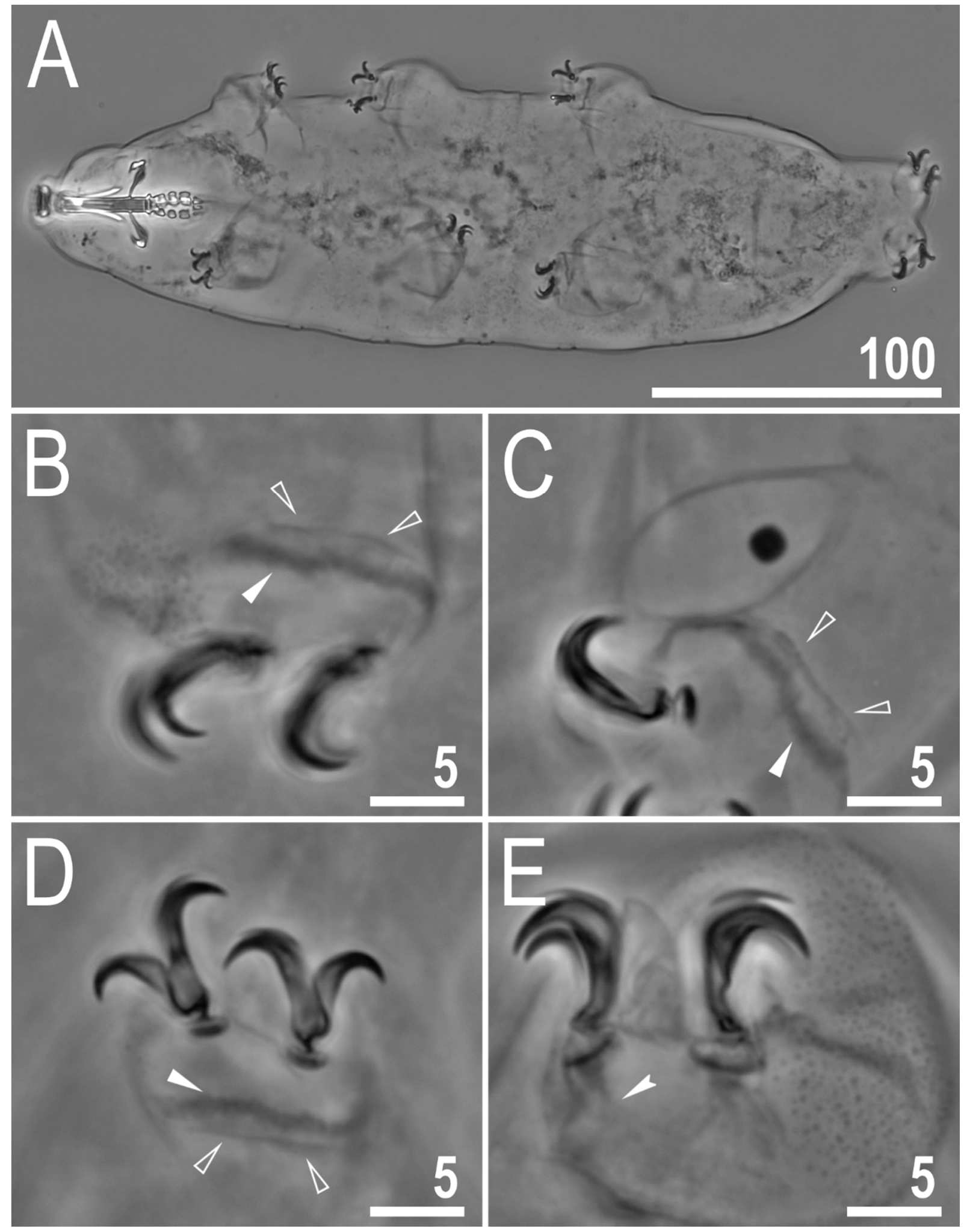

Figure 7. Mesobiotus marmoreus sp. nov.-PCM image of habitus and leg's cuticle morphology and claws: (A)—dorso-ventral projection (holotype); (B)—granulation on the external surface of leg III (holotype); (C)—a pulvinus-like cuticular bulge on the internal surface of leg II (paratype); (D)—claws I with smooth lunulae (holotype); (E)—granulation on dorsal and lateral surface and claws on leg IV (paratype). Filled flat arrowheads indicate a single continuous cuticular bar above the claws, empty flat arrowheads indicate paired muscles attachments, filled indented arrowhead indicates horseshoe structure connecting the anterior and the posterior claw. Scale bars in $\mu \mathrm{m}$. 

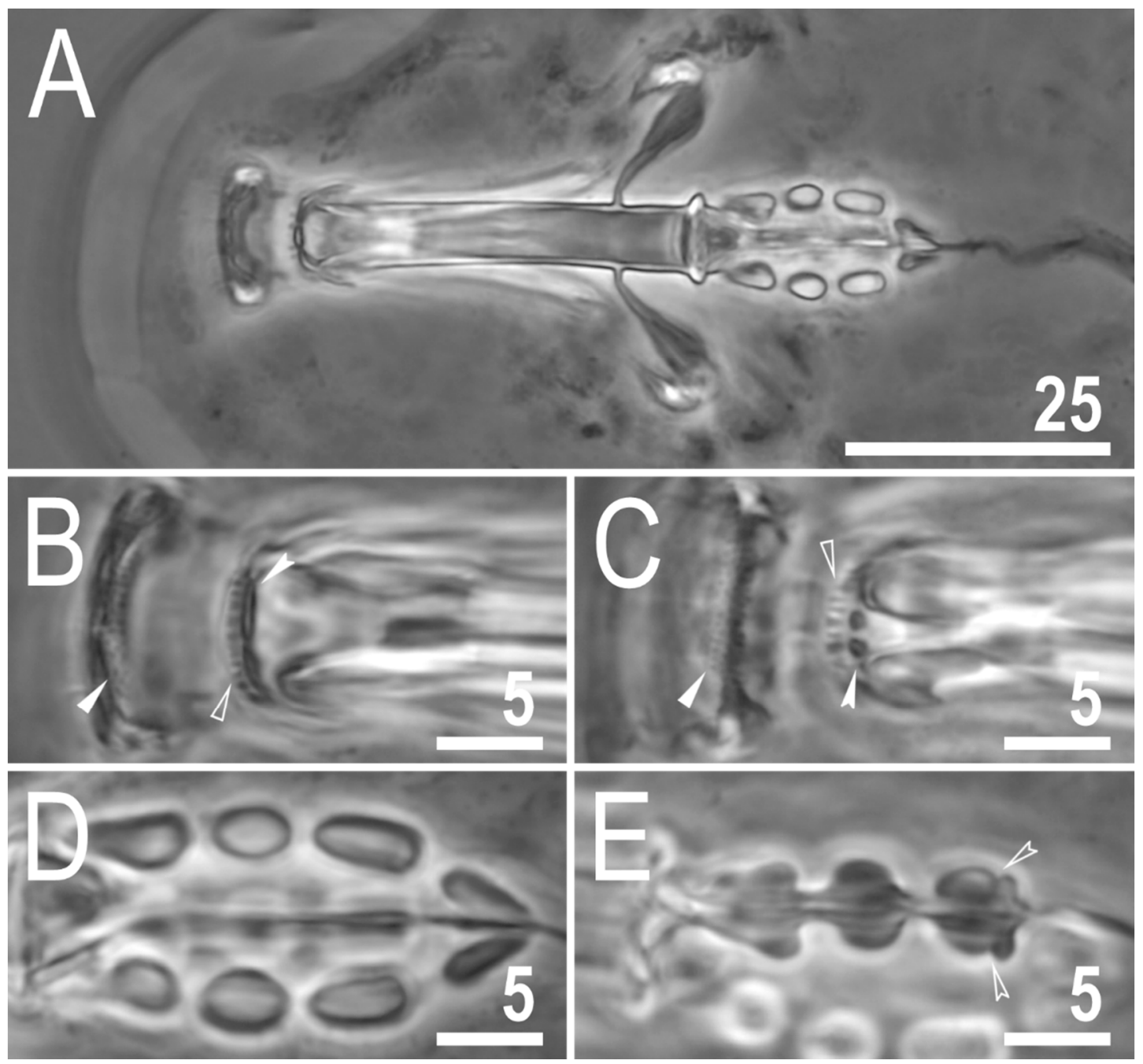

Figure 8. Mesobiotus marmoreus sp. nov.-PCM images of the buccal apparatus: (A) —an entire buccal apparatus (paratype); $(\mathbf{B}, \mathbf{C})$ - the oral cavity armature, dorsal and ventral teeth, respectively (paratype); (D,E)—placoid morphology, dorsal and ventral placoids, respectively (paratype). Filled flat arrowheads indicate the first band of tenth, empty flat arrowheads indicate the second band of teeth, filled indented arrowheads indicate the third band of teeth, empty indented arrowheads indicate subterminal constrictions in the third macroplacoid. Scale bars in $\mu \mathrm{m}$.

\subsubsection{Animals}

The body is almost transparent in small specimens and whitish in adults; after fixation in Hoyer's medium, the body is transparent (Figure 7A). Eyes are absent in alive animals. The body cuticle is smooth, i.e., without pores or sculpturing. Granulation is present on the external surface of all legs I-III (Figure 7B) as well as on the lateral and dorsal surfaces of legs IV (Figure 1E). A cuticular bulge/fold, resembling a pulvinus, is present on the internal surface of legs I-III (Figure 7C). Claws are of the Mesobiotus type, with a peduncle connecting the claw to the lunula, a basal septum and well-developed accessory points situated in parallel to the primary branch (Figure 7D,E). Lunulae under all claws are smooth (Figure 7D,E). A single continuous cuticular bar and double muscle attachments are present above claws I-III (Figure 7B-D), whereas a horseshoe-shaped structure connects the anterior and posterior lunulae on claws IV (Figure 7E). 

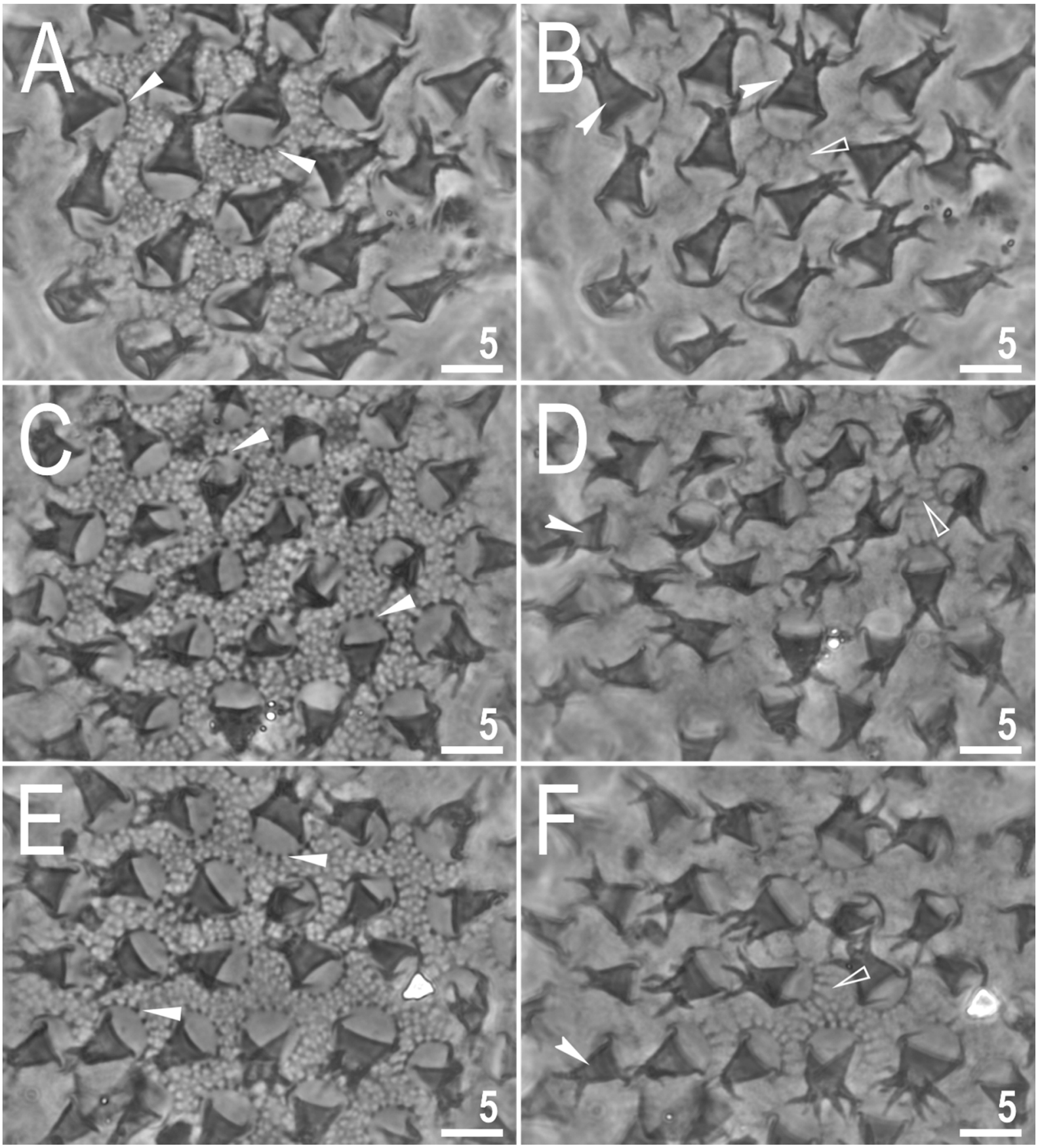

Figure 9. Mesobiotus marmoreus sp. nov.-PCM images of the egg surface under $\times 1000$ magnification. Each row represents a different egg whereas columns represent different focus levels. Filled flat arrowheads indicate crowns of thickenings around the process bases, empty flat arrowheads indicate extending striae radiating from processes bases, filled indented arrowheads indicate faint thickenings and darkening in processes trunk that in SEM are visible as annulations. Scale bars in $\mu \mathrm{m}$. 

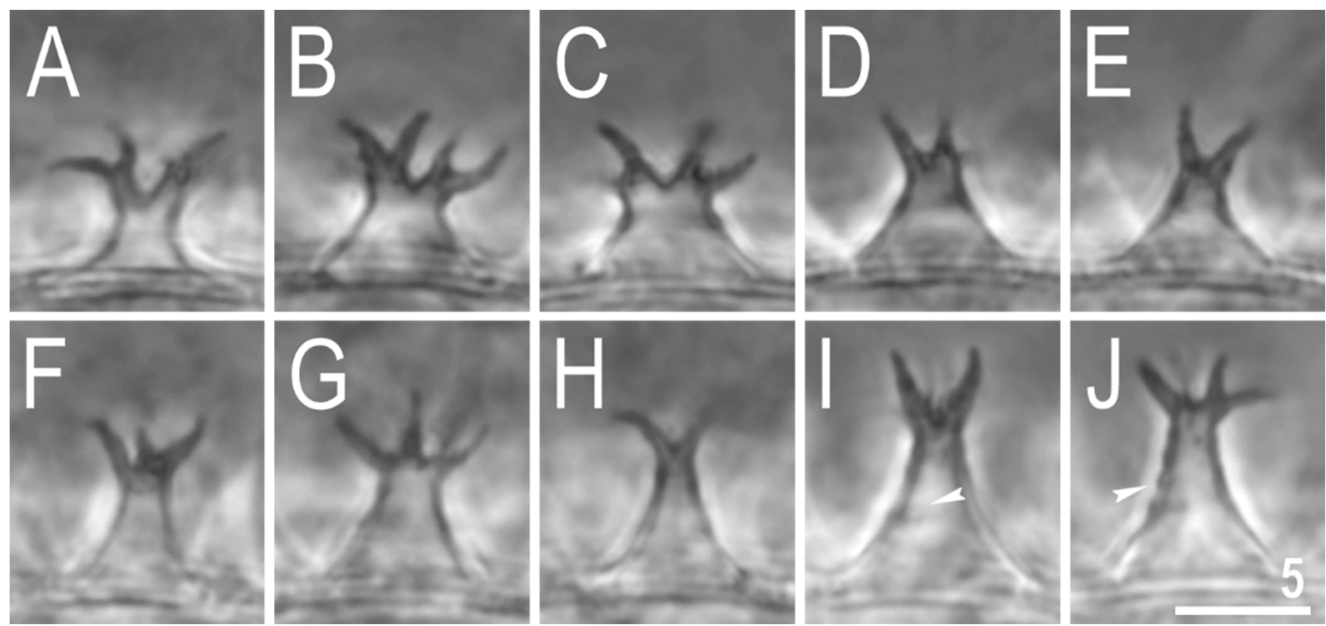

Figure 10. Mesobiotus marmoreus sp. nov.-PCM images of the egg processes midsections under $\times 1000$ magnification. Filled indented arrowheads indicate faint thickenings and darkening that in SEM are visible as annulations (see Figure 11). Scale bar in $\mu \mathrm{m}$.
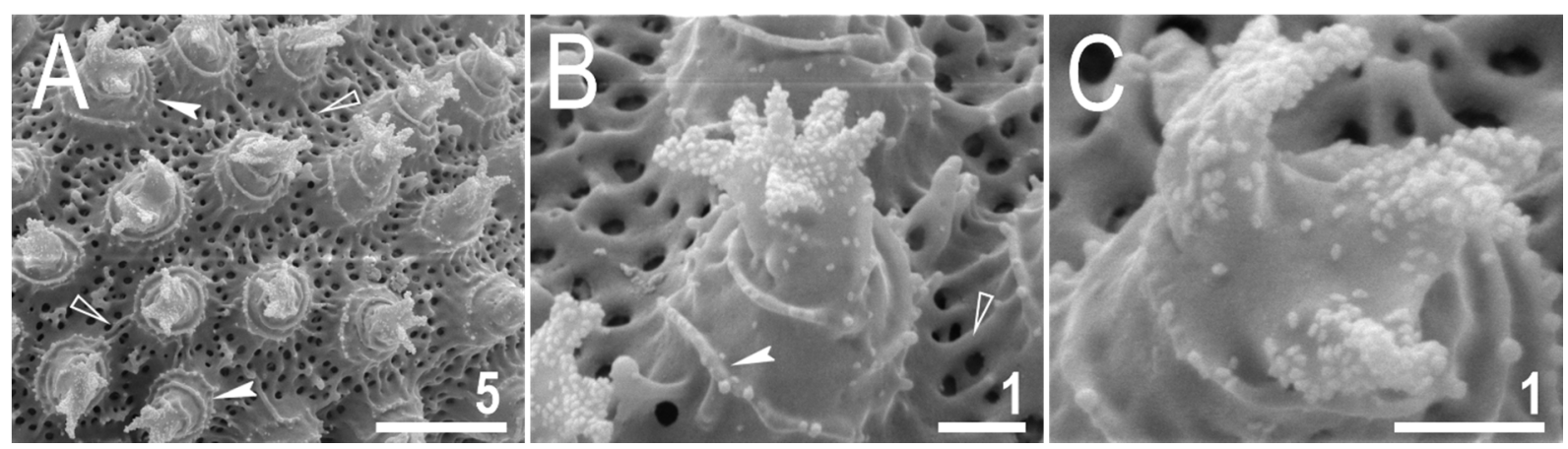

Figure 11. Mesobiotus marmoreus sp. nov.—SEM images of eggs: (A)—details of the egg surface; (B)—egg process; (C)—top part of the processes divided into several tentacular arms covered with fine granulation. Empty flat arrowheads indicate elevated bars of the reticulum that are visible as extending striae radiating from processes bases in PCM (see Figure 9), filled indented arrowheads indicate annulations present on the process trunks. Scale bars in $\mu \mathrm{m}$.

The mouth is antero-ventral. The Bucco-pharyngeal apparatus is of the Macrobiotus type, with the ventral lamina and ten small peribuccal lamellae (Figure 8A). The oral cavity armature is well developed and composed of three bands of teeth (Figure 8B,C). The first band of teeth is composed of numerous small granules arranged in several discrete rows situated anteriorly in the oral cavity, just behind the bases of the peribuccal lamellae (Figure $8 \mathrm{~B}, \mathrm{C}$ ). The second band of teeth is situated between the ring fold and the third band of teeth and is composed of ridges parallel to the main axis of the buccal tube that are larger than those in the first band (Figure 8B,C). The teeth of the third band are located within the posterior portion of the oral cavity, between the second band of teeth and the buccal tube opening (Figure 8B,C). The third band of teeth is discontinuous and divided intodorsal and ventral portions. Under PCM, dorsal teeth are visible as two lateral and one median transverse ridges/crests (Figure 8B) whereas ventral teeth consist of two lateral transverse ridges/crests between which two or three roundish and separated ventromedian teeth are present (Figure 8C). The pharyngeal bulb is ovoid (Figure 8A), with triangular apophyses, three rod-shaped macroplacoids and a large, elongated drop-shaped microplacoid placed close to the third macroplacoid (Figure 8D,E). The macroplacoid length sequence is $2<3<1$. The first macroplacoid is anteriorly narrowed and the third has a clearly defined sub-terminal constriction (Figure 8E). Measurements and statistics are presented in Table 5. 


\subsubsection{Eggs}

The eggs are spherical, whitish and laid freely, with processes in the shape of cones with multiple apices (Figures 9-11). In PCM, the egg surface is covered with a fine but clearly visible reticulum, typically with $2-5$ rows of meshes between the neighbouring processes (Figure 9A). In SEM, the egg surface appears between porous and reticulated states, with pores $(0.2-0.5 \mu \mathrm{m}$ in diameter) similar in size to the width of mesh nodes and bars (0.1-0.6 $\mu \mathrm{m}$; Figure 11A). In PCM, crowns of granular dark thickenings are present around the base of processes (Figure 9A,C,E), which extend into striae radiating from the process bases (Figure 9B,D,F). In SEM, these striae are also visible as elevated bars and nodes of the reticulum (Figure 11A,B). The egg processes exhibit one to three latitudinal annulations that are clearly visible only in SEM (Figure 11), whereas in PCM, they are only sometimes visible as faint, darkened lines in the process trunk (Figure 9B,D,F) or as faintly visible, thickening in the process midsection (Figure 10I,J). Under SEM, the annulations are seen as laminal rings with small granules present on their margins, giving the serrated impression (Figure 11). The process apex divided into multiple (typically 3-6), slender, varying in length, tentacular arms (Figures 9-11), which are covered by fine granulation, visible only in SEM (Figure 11). Measurements and statistics are presented in Table 6.

\subsubsection{Reproduction}

The examination of all individuals, freshly mounted in Hoyer's medium, under PCM has not revealed any testis or spermathecae filled with spermatozoa. Thus, it is most likely that the new species is parthenogenetic.

\subsubsection{DNA Sequences}

The obtained sequences for all four molecular markers analysed in this study were of good quality and were represented by single haplotypes.

The 18S rRNA sequences (GenBank: OL257856-8), 1009 bp long.

The 28S rRNA sequences (GenBank: OL257868-70), 799 bp long.

The ITS-2 sequences (GenBank: OL257861-3), 405 bp long.

The COI sequences (GenBank: OL311516-8), 658 bp long;.

\subsection{Phylogenetic Position of the New Taxa}

The phylogenetic analysis of taxa belonging to the genus Mesobiotus did not indicate M. harmsworthi and M. furciger groups to be monophyletic (Figure 12). Species representing each of these groups are intermixed in the obtained tree (Figure 12). The analysis indicated Mesobiotus imperialis sp. nov. is closely related to Mesobiotus philippinicus (Figure 12). This is also obvious when inspecting the genetic distances that show a large amount of similarity between DNA sequences of nuclear markers (p-distance; $18 \mathrm{~S}$ rRNA: $0.0 \%, 28 \mathrm{~S}$ rRNA: $2.3 \%$; $\mathrm{SM} .05)$. The same occurred in case of the COI dataset, where the lowest genetic distance out of all comparisons with other Mesobiotus taxa was 16.5\% (p-distance; SM.05). In the tree, the closest relative of Mesobiotus marmoreus sp. nov. is Mesobiotus dilimanensis Itang, Stec, Mapalo Mirano-Bascos \& Michalczyk, 2020 [50] (Figure 12). The genetic distances between these two species are also the lowest out of all conducted comparisons (p-distance; 18S rRNA: 0.1\%, 28 S rRNA: 1.5\%, ITS-2: 9.9\%, COI: 21.1\%; SM.05). 

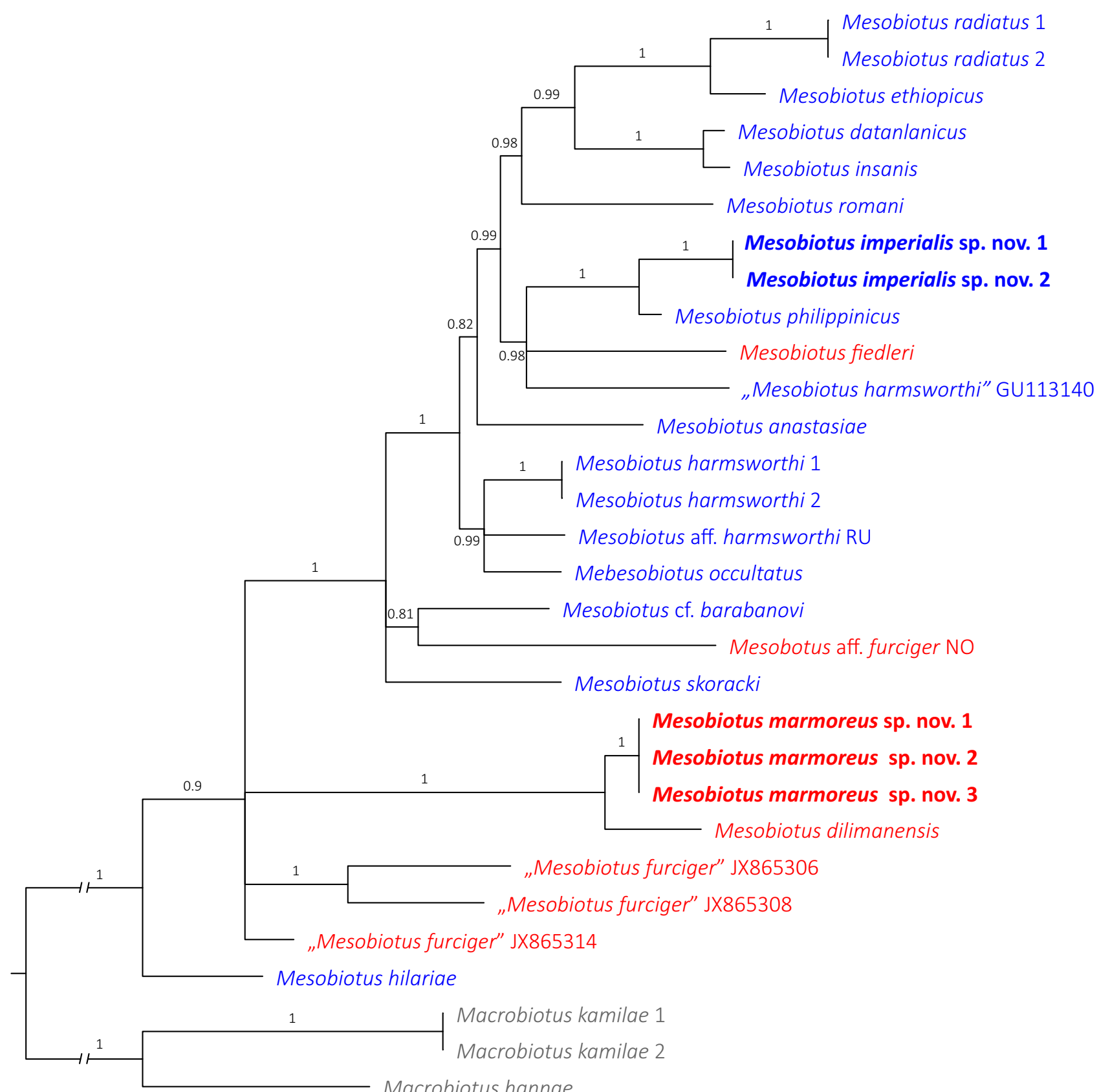

Macrobiotus hannae

Figure 12. The Bayesian Inference (BI) phylogeny constructed from concatenated sequences (18S rRNA + 28S rRNA + ITS-2 + COI) of the genus Mesobiotus. Numbers at nodes indicate Bayesian posterior probability; nodes with values below 0.80 have been collapsed. Taxa newly sequenced in this study are marked with bolded font. Taxa of the M. harmsworthi and M. furciger complex are indicated by blue and red font, respectively. Outgroup is indicated by grey font. Quotation marks indicate misidentified Mesobiotus species or species with uncertain species identification. Scale bar represents substitutions per position.

\section{Discussion}

\subsection{Differential Diagnosis of Mesobiotus imperialis sp. nov.}

The new species belong to the informal Mesobiotus harmsworthi morphogroup as it exhibits rather large conical processes. After using the dichotomous key by Kaczmarek et al. [7] and Tumanov [8], the new species have been identified as Mesobiotus philippinicus known only from its type locality in Philippines [30]. Importantly, it should be also noted that both men- 
tioned keys contain a mistake saying that M. philippinicus has the first band of teeth in the oral cavity armature not visible in light microscopy, which is not true [30]. However, despite the phenotypic match, the genetic data and phylogenetic analysis clearly indicate the Vietnamese population to be a distinct species. Closer comparison revealed minute morphological and morphometric differences based on which the new species is differentiated.

Mesobiotus imperialis sp. nov. differs from M. philippinicus by the presence of granulation on all legs that is visible in light microscopy (only granulation on leg IV faintly visible in some specimens of $M$. philippinicus), evidently more pronounced thickenings surrounding the bases of egg processes in the new species (crown of thickenings surrounding processes bases less pronounced in M. philippinicus), unevenly distributed depressions and faint tubercles in the egg processes walls (processes walls are smooth, without mentioned depressions and tubercles in M. philippinicus, with this character observable only in SEM), and having conical processes always stretched (egg processes covered with wrinkles forming a rose-like whorl in M. philippinicus; remark: Based on personal observations, this character is most probably an artefact caused by the culture environment and, importantly, M. philippinicus was described based on specimens form laboratory isoline). The morphometric comparisons of both populations revealed that ranges of measured characters greatly overlap. Therefore, statistical testing was involved to check for eventual differences between analysed species. T-test comparisons of morphometric characters revealed statistically significant differences between these two populations in almost all absolute and all relative claws measurements, with claws being larger in M. philippinicus ( $\mathrm{p}_{\mathrm{B}-\mathrm{H}}<<0.002$; SM.03). Out of the remaining animals' measurements, $p t$ values for stylet support insertion point as well as ventral lamina length were also significantly different and larger in $M$. philippinicus and the new species, respectively ( $\mathrm{p}_{\mathrm{B}-\mathrm{H}}<<0.002 ; \mathrm{SM} .03$ ). Moreover, there were also significant differences in egg measurements such as egg bare diameter, process height, process base-height ratio and inter-process distances ( $\mathrm{p}_{\mathrm{B}-\mathrm{H}}<<0.007$; SM.03). Nevertheless, as stated above, these latter differences in egg dimensions should be treated with great caution as they might be caused by culturing conditions.

\subsection{Differential Diagnosis of Mesobiotus marmoreus sp. nov.}

The new species belongs to the informal Mesobiotus furciger morphogroup as it exhibits rather small conical processes with branched apices. After using the dichotomous key by Kaczmarek et al. [7] and Tumanov [8], the new species could not be identified. By having reticulated egg surface between processes (at least visible as such in light microscopy) the new species is similar to the following taxa: Mesobiotus creber (Pilato \& Lisi, 2009) [63], M. dilimanensis, Mesobiotus divergens (Binda, Pilato \& Lisi, 2005) [64], Mesobiotus kovalevi (Tumanov, 2004) [65] and Mesobiotus siamensis (Tumanov, 2006) [66], but it differs specifically from the following:

Mesobiotus creber known only from the Seychelles Islands [63] by the presence of granulation on all legs (the granulation absent in $M$. creber); the medio-ventral tooth of the third band of teeth usually subdivided into three roundish teeth (only up to two roundish teeth present in $M$. creber); a more anteriorly positioned stylet support insertion point ( $p t=76.2-77.8$ in the new species vs. $p t=80.0-80.9$ in $M$. creber); a more evident subdivisions of process apices that resemble tentacular arms (process apices subdivided into short, nodular terminal branches in M. creber); a larger egg bare diameter (63.4-69.6 $\mu \mathrm{m}$ in the new species vs. 52-60 $\mu \mathrm{m}$ in $M$. creber); a larger egg full diameter (77.9-82.2 $\mu \mathrm{m}$ in the new species vs. 59-66 $\mu \mathrm{m}$ in $M$. creber).

Mesobiotus dilimanensis, known only from the Philippines [50], by a different macroplacoid sequence $(2<3<1$ in the new species vs. $2<1=3$ in $M$. dilimanensis); a more anteriorly positioned stylet support insertion point ( $p t=76.2-77.8$ in the new species vs. $p t=78.0-81.4$ in $M$. dilimanensis); longer primary branches of external claws I $(6.4-8.6 \mu \mathrm{m}$ in the new species vs. 8.8-12.1 $\mu \mathrm{m}$ in $M$. dilimanensis); longer primary branches of external and internal claws II (7.0-8.8 and 6.2-8.9 $\mu \mathrm{m}$, respectively in the new species vs. 10.0-12.9 and 9.2-12.0 $\mu \mathrm{m}$, respectively in $M$. dilimanensis); longer primary branches of anterior and 
posterior claws IV (7.5-9.5 and 8.0-10.1 $\mu \mathrm{m}$, respectively in the new species vs. 9.7-14.8 and 10.7-14.8 $\mu \mathrm{m}$, respectively in $M$. dilimanensis); the presence of subdivisions in processes apices that resemble slender tentacular arms (process apices subdivided into multiple short, nodular, finger-like apices in $M$. dilimanensis); the presence of one to three latitudinal annulations on the processes trunks that are seen as laminal rings with small granules present on their margins giving the serrated impression (small globular tubercles present on the processes trunks in $M$. dilimanensis); a larger number of processes on the egg circumference (26-30 in the new species vs. 18-24 in M. dilimanensis).

Mesobiotus divergens, known only from New Zealand [64], by the presence of granulation on all legs (the granulation absent in $M$. divergens); the morphology of the stylet sheaths (typical in the new species vs. caudally thickened lateral portions of stylet sheaths in $M$. divergens); a relatively longer placoid row ( $p t=53.7-61.2$ in the new species vs. $p t=45.4-51.6$ in M. divergens); a relatively larger microplacoid $(p t=9.6-12.7$ in the new species vs. $p t=7.1-7.4$ in $M$. divergens); a larger number of processes on the egg circumference (26-30 in the new species vs. 17 in $M$. divergens); a different point of division of the egg process apex (division closer to the process tip in the new species vs. division at half of the process height in $M$. divergens); the presence of subdivisions in process apices that resemble slender tentacular arms (processes subdivided into two or three stout branches that might be further subdivided into multiple, finger-like, nodular apices in $M$. divergens).

Mesobiotus kovalevi, known only from New Zealand [65], by the absence of eyes; the presence of granulation on all legs (the granulation absent in $M$. kovalevi); the presence of three bands of teeth in the oral cavity (the first and the second band of teeth absent or invisible in light microscopy in M. kovalevi); the presence of a medio ventral tooth of the third band of teeth subdivided into two or three roundish teeth (a single roundish medio-ventral tooth present in M. kovalevi); a different morphology of egg processes (in light microscopy stout processes with smooth trunks and apices divided into multiple slender, tentacular arms in the new species vs. elongated, conical processes only sometimes subdivided at the top with trunks covered with irregularly distributed minute spines in $M$. kovalevi); a smaller egg bare diameter (63.4-69.6 $\mu \mathrm{m}$ in the new species vs. $86-95 \mu \mathrm{m}$ in $M$. kovalevi); shorter egg processes (5.6-8.8 $\mu \mathrm{m}$ in the new species vs. $12-17 \mu \mathrm{m}$ in M. kovalevi), a slightly larger number of processes on the egg circumference (26-30 in the new species vs. up to 25 in M. kovalevi); a smaller meshes in the reticulum covering the egg surface between processes (mashes diameter $0.2-0.5 \mu \mathrm{m}$ in the new species vs. nearly $1 \mu \mathrm{m}$ in $M$. kovalevi).

Mesobiotus siamensis, known only from Thailand [66], by the presence of granulation on all legs (the granulation absent in M. siamensis); a more-developed first band of teeth in the oral cavity (always clearly visible in light microscopy in the new species vs. barely visible even in largest specimens of $M$. siamensis); the presence of a medio-ventral tooth of the third band of teeth subdivided into two or three roundish teeth (a medio-ventral tooth only almost broken into several granules in M. siamensis); a different morphology of lunulae IV (smooth in the new species vs. with undulated margins in M. siamensis); a different morphology of egg processes (in light microscopy stout processes with smooth trunks and apices divided into multiple slender, tentacular arms in the new species vs. bottle-shaped processes with an evidently elongated distal part that is subdivided at the top into short and pointed apices in M. siamensis); shorter processes (5.6-8.8 $\mu \mathrm{m}$ in the new species vs. $10.7-11.8 \mu \mathrm{m}$ in M. siamensis); narrower process bases (3.4-6.5 $\mu \mathrm{m}$ in the new species vs. 7.4-10.0 $\mu \mathrm{m}$ in M. siamensis); a smaller egg bare diameter (63.4-69.6 $\mu \mathrm{m}$ in the new species vs. $70.3-77.7 \mu \mathrm{m}$ in $M$. siamensis); a larger number of processes on the egg circumference (26-30 in the new species vs. up to 22 in M. siamensis).

\subsection{Conclusions}

Thanks to the integrative analysis of the two newly found Mesobiotus populations and their descriptions, as new to science, the number of Vietnamese tardigrade species was elevated to 36. The two new taxa presented herein have their closest relatives in Philippines as recovered by phylogenetic analysis also reflected in morphological similarities. This 
finding is not surprising when considering the geographic distance and the fact that both these regions belong to the generally speaking Oriental zoogeographic realm. Therefore, the more recent split of these evolutionary lineages should have been expected.

Supplementary Materials: The following are available online at https://www.mdpi.com/article/10 .3390/d13110605/s1, SM.01. Raw morphometric data of Mesobiotus imperialis sp. nov. SM.02. Raw morphometric data of Mesobiotus marmoreus sp. nov. SM.03. Results of T-test comparisons. SM.04. Best-fit partitioning scheme and models suggested by PartitionFinder. SM.05. Uncorrected pairwise genetic distances.

Funding: The study was supported by the Preludium programme of the National Science Centre, Poland (grant no. 2018/31/N/NZ8/03096 to DS). During this study, DS was supported by the Foundation for Polish Science (FNP).

Institutional Review Board Statement: Not applicable.

Data Availability Statement: The author confirms that the data supporting the findings of this study are available within the article and its Supplementary Materials. The DNA sequences generated in this study are available in GenBank.

Acknowledgments: I am especially grateful to Krzysztof Miler for his magnificent help with samples collection.

Conflicts of Interest: The author declares no conflict of interest.

\section{References}

1. Nelson, D.R.; Guidetti, R.; Rebecchi, L. Phylum Tardigrada. In Ecology and General Biology, 4th ed.; Thorp, J., Rogers, D.C., Eds.; Thorp and Covich's Freshwater Invertebrates; Academic Press Inc.: Cambridge, MA, USA, 2015; Volume 1, pp. 347-380. [CrossRef]

2. Guidetti, R.G.; Bertolani, R.B. Tardigrade taxonomy: An updated check list of the taxa and a list of characters for their identification. Zootaxa 2005, 845, 1-46. [CrossRef]

3. Degma, P.; Guidetti, R. Notes to the current checklist of Tardigrada. Zootaxa 2007, 1579, 41-53. [CrossRef]

4. Degma, P.; Bertolani, R.; Guidetti, R. Actual Checklist of Tardigrada Species. Available online: https://doi.org/10.25431/11380_1 178608 (accessed on 26 April 2021).

5. Vecchi, M.; Cesari, M.; Bertolani, R.; Jönsson, K.I.; Rebecchi, L.; Guidetti, R. Integrative systematic studies on tardigrades from Antarctica identify new genera and new species within Macrobiotoidea and Echiniscoidea. Invertebr. Syst. 2016, 30, 303-322. [CrossRef]

6. Stec, D.; Vecchi, M.; Calhim, S.; Michalczyk, Ł. New multilocus phylogeny reorganises the family Macrobiotidae (Eutardigrada) and unveils complex morphological evolution of the Macrobiotus hufelandi group. Mol. Phylogenetics Evol. 2020, 160, 106987. [CrossRef] [PubMed]

7. Kaczmarek, Ł.; Bartylak, T.; Stec, D.; Kulpa, A.; Kepel, M.; Kepel, A.; Roszkowska, M. Revisiting the genus Mesobiotus Vecchi et al. 2016 (Eutardigrada, Macrobiotidae)—remarks, updated dichotomous key and an integrative description of new species from Madagascar. Zoöl. Anz. A J. Comp. Zoöl. 2020, 287, 121-146. [CrossRef]

8. Tumanov, D.V. Integrative description of Mesobiotus anastasiae sp. nov. (Eutardigrada, Macrobiotoidea) and first record of Lobohalacarus (Chelicerata, Trombidiformes) from the Republic of South Africa. Eur. J. Taxon. 2020, 726, 102-131. [CrossRef]

9. Kaczmarek, Ł.; Zawierucha, K.; Buda, J.; Stec, D.; Gawlak, M.; Michalczyk, Ł.; Roszkowska, M. An integrative redescription of the nominal taxon for the Mesobiotus harmsworthi group (Tardigrada: Macrobiotidae) leads to descriptions of two new Mesobiotus species from Arctic. PLoS ONE 2018, 13, e0204756. [CrossRef]

10. Węglarska, B. Die Tardigraden Vietnams. Acta Soc. Zool. Bohemoslov. 1962, 26, 300-307.

11. Iharos, G. Einige Angaben zur Tardigradenfauna Vietnams. Opusc. Zool. Bp. 1969, 9, $273-277$.

12. Pilato, G.; Binda, M.G. Isohypsibius barbarae, a new species of eutardigrade from Vietnam. Bolletino Delle Sedute Dell'accademia Gioenia Di Sci. Nat. Catania 2002, 35, 637-642.

13. Beasley, C.W.; Kaczmarek, Ł.; Michalczyk, Ł. Redescription of Doryphoribius vietnamensis (Iharos, 1969) comb. nov. on the basis of the holotype and additional material from China. Acta Zool. Acad. Sci. Hung. 2006, 52, 367-372. [CrossRef]

14. Tchesunov, A.V. Marine tardigrade Halechiniscus jejuensis Chang et Rho, 2002 (Arthrotardigrada: Halechiniscidae) found in Vietnam. Invertzool 2011, 8, 79-85. [CrossRef]

15. Stec, D. Mesobiotus datanlanicus sp. nov., a new tardigrade species (Macrobiotidae: Mesobiotus harmsworthi group) from Lâm Đồng Province in Vietnam. Zootaxa 2019, 4679, 164-180. [CrossRef] [PubMed]

16. Gasiorek, P.; Vončina, K.; Nelson, D.R.; Michalczyk, Ł. The importance of being integrative: A remarkable case of synonymy in the genus Viridiscus (Heterotardigrada: Echiniscidae). Zool. Lett. 2021, in press. [CrossRef]

17. Murray, J. XXV.-Arctic Tardigrada, collected by Wm. S. Bruce. Trans. R. Soc. Edinb. 1907, 45, 669-681. [CrossRef] 
18. Stec, D.; Smolak, R.; Kaczmarek, Ł.; Michalczyk, Ł. An integrative description of Macrobiotus paulinae sp. nov. (Tardigrada: Eutardigrada: Macrobiotidae: Hufelandi group) from Kenya. Zootaxa 2015, 4052, 501-526. [CrossRef] [PubMed]

19. Morek, W.; Stec, D.; Gąsiorek, P.; Schill, R.O.; Kaczmarek, Ł.; Michalczyk, Ł. An experimental test of eutardigrade preparation methods for light microscopy. Zoöl. J. Linn. Soc. 2016, 178, 785-793. [CrossRef]

20. Coughlan, K.; Stec, D. Two new species of the Macrobiotus hufelandi complex (Tardigrada: Eutardigrada: Macrobiotidae) from Australia and India, with notes on their phylogenetic position. Eur. J. Taxon. 2019, 573, 1-38. [CrossRef]

21. Coughlan, K.; Michalczyk, Ł.; Stec, D. Macrobiotus caelestis sp. nov., a New Tardigrade Species (Macrobiotidae: Hufelandi Group) from the Tien Shan Mountains (Kyrgyzstan). Ann. Zoöl. 2019, 69, 499. [CrossRef]

22. Stec, D.; Gąsiorek, P.; Morek, W.; Kosztyła, P.; Zawierucha, K.; Michno, K.; Kaczmarek, Ł.; Prokop, Z.M.; Michalczyk, Ł. Estimating optimal sample size for tardigrade morphometry. Zoöl. J. Linn. Soc. 2016, 178, 776-784. [CrossRef]

23. Pilato, G.; Binda, M.G. Definition of families, subfamilies, genera and subgenera of the Eutardigrada, and keys to their identification. Zootaxa 2010, 2404, 1-54. [CrossRef]

24. Michalczyk, Ł.; Kaczmarek, Ł. A description of the new tardigrade Macrobiotus reinhardti (Eutardigrada: Macrobiotidae, harmsworthi group) with some remarks on the oral cavity armature within the genus Macrobiotus Schultze. Zootaxa 2003, 331, 1-24. [CrossRef]

25. Kaczmarek, Ł.; Michalczyk, Ł. The Macrobiotus hufelandi group (Tardigrada) revisited. Zootaxa 2017, 4363, 101-123. [CrossRef]

26. Kaczmarek, Ł.; Cytan, J.; Zawierucha, K.; Diduszko, D.; Michalczyk, Ł. Tardigrades from Peru (South America), with descriptions of three new species of Parachela. Zootaxa 2014, 3790, 357-379. [CrossRef]

27. Kiosya, Y.; Pogwizd, J.; Matsko, Y.; Vecchi, M.; Stec, D. Phylogenetic position of two Macrobiotus species with a revisional note on Macrobiotus sottilei Pilato, Kiosya, Lisi \& Sabella, 2012 (Tardigrada: Eutardigrada: Macrobiotidae). Zootaxa 2021, 4933, 113-135. [CrossRef]

28. Pilato, G. Analisi di nuovi caratteri nello studio degli Eutardigradi. Animalia 1981, 8, 51-57.

29. Michalczyk, Ł.; Kaczmarek, Ł. The Tardigrada Register: A comprehensive online data repository for tardigrade taxonomy. J. Limnol. 2013, 72, e22. [CrossRef]

30. Mapalo, M.A.; Stec, D.; Mirano-Bascos, D.; Michalczyk, Ł. Mesobiotus philippinicus sp. nov., the first limnoterrestrial tardigrade from the Philippines. Zootaxa 2016, 4126, 411-426. [CrossRef]

31. R Core Team. R: A Language and Environment for Statistical Computing; R Foundation for Statistical Computing: Vienna, Austria, 2021; Available online: http:/ / www.R-project.org/ (accessed on 26 April 2021).

32. Benjamini, Y.; Hochberg, Y. Controlling the False Discovery Rate: A Practical and Powerful Approach to Multiple Testing. J. R. Stat. Soc. Ser. B Methodol. 1995, 57, 289-300. [CrossRef]

33. Casquet, J.; Thébaud, C.; Gillespie, R.G. Chelex without boiling, a rapid and easy technique to obtain stable amplifiable DNA from small amounts of ethanol-stored spiders. Mol. Ecol. Resour. 2011, 12, 136-141. [CrossRef] [PubMed]

34. Stec, D.; Kristensen, R.M.; Michalczyk, Ł. An integrative description of Minibiotus ioculator sp. nov. from the Republic of South Africa with notes on Minibiotus pentannulatus Londoño et al., 2017 (Tardigrada: Macrobiotidae). Zoöl. Anz. A J. Comp. Zoöl. 2020, 286, 117-134. [CrossRef]

35. Hall, T.A. BioEdit: A user-friendly biological sequence alignment editor and analysis program for Windows 95/98/NT. Nucleic Acids Symp. Ser. 1999, 41, 95-98.

36. Kumar, S.; Stecher, G.; Tamura, K. MEGA7: Molecular Evolutionary Genetics Analysis Version 7.0 for Bigger Datasets. Mol. Biol. Evol. 2016, 33, 1870-1874. [CrossRef]

37. Stec, D.; Zawierucha, K.; Michalczyk, Ł. An integrative description of Ramazzottius subanomalus (Biserov, 1985 (Tardigrada) from Poland. Zootaxa 2017, 4300, 403-420. [CrossRef]

38. Gąsiorek, P.; Stec, D.; Zawierucha, K.; Kristensen, R.M.; Michalczyk, Ł. Revision of Testechiniscus Kristensen, 1987 (Heterotardigrada: Echiniscidae) refutes the polar-temperate distribution of the genus. Zootaxa 2018, 4472, 261-297. [CrossRef]

39. Mironov, S.V.; Dabert, J.; Dabert, M. A new feather mite species of the genus Proctophyllodes Robin, 1877 (Astigmata: Proctophyllodidae) from the Long-tailed Tit Aegithalos caudatus (Passeriformes: Aegithalidae)—morphological description with DNA barcode data. Zootaxa 2012, 3253, 54-61. [CrossRef]

40. Stec, D.; Morek, W.; Gasiorek, P.; Michalczyk, Ł. Unmasking hidden species diversity within the Ramazzottius oberhaeuseri complex, with an integrative redescription of the nominal species for the family Ramazzottiidae (Tardigrada: Eutardigrada: Parachela). Syst. Biodivers. 2018, 16, 357-376. [CrossRef]

41. Astrin, J.J.; Stüben, P.E. Phylogeny in cryptic weevils: Molecules, morphology and new genera of western Palaearctic Cryptorhynchinae (Coleoptera:Curculionidae). Invertebr. Syst. 2008, 22, 503-522. [CrossRef]

42. Nowak, B. An integrative description of Macrobiotus hannae sp. nov. (Tardigrada: Eutardigrada: Macrobiotidae: Hufelandi group) from Poland. Turk. J. Zoöl. 2018, 42, 269-286. [CrossRef]

43. Katoh, K.; Misawa, K.; Kuma, K.; Miyata, T. MAFFT: A novel method for rapid multiple sequence alignment based on fast Fourier transform. Nucleic Acids Res. 2002, 30, 3059-3066. [CrossRef]

44. Katoh, K.; Toh, H. Recent developments in the MAFFT multiple sequence alignment program. Briefings Bioinform. 2008, 9, 286-298. [CrossRef]

45. Vaidya, G.; Lohman, D.J.; Meier, R. SequenceMatrix: Concatenation software for the fast assembly of multi-gene datasets with character set and codon information. Cladistics 2011, 27, 171-180. [CrossRef] 
46. Lanfear, R.; Frandsen, P.B.; Wright, A.M.; Senfeld, T.; Calcott, B. PartitionFinder 2: New Methods for Selecting Partitioned Models of Evolution for Molecular and Morphological Phylogenetic Analyses. Mol. Biol. Evol. 2017, 34, 772-773. [CrossRef]

47. Ronquist, F.; Huelsenbeck, J.P. MrBayes 3: Bayesian phylogenetic inference under mixed models. Bioinformatics 2003, 19, 1572-1574. [CrossRef] [PubMed]

48. Rambaut, A.; Drummond, A.J. Tracer v1.6. 2014. Available online: http://beast.bio.ed.ac.uk/Tracer (accessed on 8 September 2021).

49. Stec, D.; Kristensen, R.M. An integrative description of Mesobiotus ethiopicus sp. nov. (Tardigrada: Eutardigrada: Parachela: Macrobiotidae: Harmsworthi group) from the northern Afrotropic region. Turk. J. Zoöl. 2017, 41, 800-811. [CrossRef]

50. Itang, L.A.M.; Stec, D.; Mapalo, M.A.; Mirano-Bascos, D.; Michalczyk, Ł. An integrative description of Mesobiotus dilimanensis, a new tardigrade species from the Philippines (Eutardigrada: Macrobiotidae: Furciger group). Raffles Bull. Zool. 2020, 68, 19-31.

51. Mapalo, M.; Stec, D.; Mirano-Bascos, D.; Michalczyk, Ł. An integrative description of a limnoterrestrial tardigrade from the Philippines, Mesobiotus insanis, new species (Eutardigrada: Macrobiotidae: Harmsworthi group). Raffles Bull. Zool. 2017, 65, 440-454.

52. Pilato, G.; Binda, M.G.; Catanzaro, R. Remarks on some tardigrades of the African fauna with the description of three new species of Macrobiotus Schultze 1834. Trop. Zoöl. 1991, 4, 167-178. [CrossRef]

53. Stec, D.; Roszkowska, M.; Kaczmarek, Ł.; Michalczyk, Ł. An integrative description of a population of Mesobiotus radiatus (Pilato, Binda \& Catanzaro, 1991) from Kenya. Turk. J. Zoöl. 2018, 42, 523-540. [CrossRef]

54. Roszkowska, M.; Stec, D.; Gawlak, M.; Kaczmarek, Ł. An integrative description of a new tardigrade species Mesobiotus romani sp. nov. (Macrobiotidae: Harmsworthi group) from the Ecuadorian Pacific coast. Zootaxa 2018, 4450, 550-564. [CrossRef]

55. Murray, J. Encystment of Tardigrada. Trans. R. Soc. Edinb. 1908, 45, 837-854. [CrossRef]

56. Czechowski, P.; Sands, C.J.; Adams, B.J.; D’Haese, C.A.; Gibson, J.A.E.; McInnes, S.J.; Stevens, M.I. Antarctic Tardigrada: A first step in understanding molecular operational taxonomic units (MOTUs) and biogeography of cryptic meiofauna. Invertebr. Syst. 2012, 26, 526-538. [CrossRef]

57. Kayastha, P.; Roszkowska, M.; Mioduchowska, M.; Gawlak, M.; Kaczmarek, Ł. Integrative Descriptions of Two New Tardigrade Species along with the New Record of Mesobiotus skorackii Kaczmarek et al., 2018 from Canada. Diversity 2021, 13, 394. [CrossRef]

58. Doyère, P.L.N. Memoire sur les Tardigrades. Ann. Des Sci. Nat. 1840, 14, 269-362.

59. Richters, F. Tardigrada. In Handbuch der Zoologie; Kükenthal, W., Krumbach, T., Eds.; Walter de Gruyter \& Co.: Berlin/Heidelberg, Germany, 1926; Volume 3, pp. 58-61.

60. Schuster, R.O.; Nelson, D.R.; Grigarick, A.A.; Christenberry, D. Systematic Criteria of the Eutardigrada. Trans. Am. Microsc. Soc. 1980, 99, 284-303. [CrossRef]

61. Thulin, G. Über die phylogenie und das system der tardigraden. Hereditas 2010, 11, 207-266. [CrossRef]

62. Marley, N.; McInnes, S.J.; Sands, C. Phylum Tardigrada: A re-evaluation of the Parachela. Zootaxa 2011, 2819, 51-64. [CrossRef]

63. Pilato, G.; Lisi, O.P.V. Tardigrades of the Seychelles Islands, with the description of three new species. Zootaxa 2009, 2124, 1-20. [CrossRef]

64. Binda, M.G.; Pilato, G.; Lisi, O.P.V. Remarks on Macrobiotus furciger Murray, 1906 and description of three new species of the furciger group (Eutardigrada, Macrobiotidae). Zootaxa 2005, 1075, 55-68. [CrossRef]

65. Tumanov, D.V. Macrobiotus kovalevi, a new species of Tardigrada from New Zealand (Eutadigrada, Macrobiotidae). Zootaxa 2004, 406, 1-8. [CrossRef]

66. Tumanov, D.V. Macrobiotus siamensis sp. n. (Eutardigrada, Macrobiotidae) from Thailand (Asia). Zootaxa 2006, 1202, 53-59. [CrossRef] 